\title{
Banking Products: You Can Take Them with You, So Why Don't You?
}

\author{
Carin van der Cruijsen ${ }^{1} \cdot$ Maaike Diepstraten ${ }^{1,2}$ (D)
}

Received: 1 August 2016 /Revised: 24 January 2017 / Accepted: 3 April 2017 /

Published online: 5 May 2017

(C) The Author(s) 2017. This article is an open access publication

\begin{abstract}
Policymakers around the world call for more competition in the banking sector. One prerequisite to achieving this is customer mobility. Despite its policy relevance, surprisingly little is known about consumers' bank switching behaviour. We show that the principal reasons to stay at one's bank are a good bank-customer relationship, practical barriers, and the perception that there is not much benefit in switching. Moreover, we find that the reported propensity to switch varies across banking products. For the main current and savings accounts, this propensity is most strongly related to the bank-customer relationship, while for mortgage loans it is especially linked to switching experience. These findings have important implications for antitrust policy; they provide an argument against using a cluster-based legal standard for the analysis of competition and in favour of a disaggregated approach. Regarding the effectiveness of hypothetical policy initiatives to lower switching barriers, we find that the reported switching propensity with current accounts is higher in the case of account number portability, while more knowledge of the existing switching service has no significant effect. Lastly, scenario analysis shows that a policy of allowing new foreign banks to enter the savings market is less promising for enhancing mobility than a policy that increases the number of domestic players.
\end{abstract}

Keywords Banking products · Switching behaviour · Barriers · Household survey $\cdot$ Financial literacy $\cdot$ Psychological factors $\cdot$ Loyalty $\cdot$ Bank competition $\cdot$ Policy initiatives

JEL Classification $D 14 \cdot G 21$

Maaike Diepstraten

m.diepstraten@ tilburguniversity.edu

De Nederlandsche Bank, Amsterdam, The Netherlands

2 Tilburg University, Tilburg, The Netherlands 


\section{Introduction}

Policymakers frequently call for more competition in the banking sector to increase the efficiency of banking services, see for example the Global Financial Development Report 2013 (Worldbank 2013), the Australian government response (2015) to the Financial System Inquiry (Murray et al. 2014) and the annual report of De Nederlandsche Bank (DNB 2015a). ${ }^{1}$ One way to stimulate competition is to lower entry barriers to attract new players. Consumer inertia is one example of such a barrier (The Netherlands Authority for Consumers and Markets [ACM] 2014). Consumer inertia means that only a small proportion of consumers switch banks, which makes it hard for new entrants to gain market share. Inertia is not only a barrier for new entrants, it also reduces competition among existing players in the market.

Prior studies have concluded that most bank customers are immobile. The UK Competition \& Markets Authority (2015a) reported in 2015 that almost $60 \%$ of account holders had not changed their main personal accounts provider in the past ten years. A report on Canada published by EY in 2013 states that $71 \%$ of Canadians have maintained their primary relationship for over a decade. In the case of the Netherlands, the ACM reports that in 2014, $73 \%$ of current account holders over 18 were still with the same bank where they opened their first account (ACM 2014). ${ }^{2}$ The European Commission (2013) concludes that mobility of consumers within Europe is low: around 10\% of payment account users switched in 2011.

Even though consumers hold different banking products with distinct characteristics, prior studies use broad and general measurements of switching as they examine switching the main bank. There is little research on consumer bank switching behaviour (e.g. Kiser 2002; Chakravarty et al. 2004; Brunetti et al. 2016). Research has mostly focused on either the relationship between firms and banks (e.g. Ongena and Smith 2001; Ioannidou and Ongena 2010) or on consumers and non-banks (e.g. Giulietti et al. 2005; Yang 2014).

At the same time, the product market considered by regulatory agencies for analysing competition in the US also consists of the cluster of commercial banking products and services (Federal Reserve 2014). Similarly, the European Commission (2006) focuses on retail banking markets as a whole in merger decisions. ${ }^{3}$ Although the clustering of banking products is convenient, identifying separate product markets may be better. Differences in mobility across banking products and the factors related to switching would provide an argument in favour of using a legal standard for analysing competition that is not based on clustering.

As a result, we research banking products separately. Our study focuses on current accounts, savings accounts, mortgage loans and revolving credit as these products are most commonly held by consumers. This approach allows us to differentiate between consumers' assets and liabilities. Our research questions are: i) Does the propensity to switch depend on the banking product? ii) What switching barriers do consumers perceive? iii) For each banking

\footnotetext{
${ }^{1}$ There is no consensus in the literature regarding the effect of competition on stability. Two opposing views are described. The competition-fragility view perceives competition as detrimental for stability as it provides banks incentives to take more risks. The competition-stability hypothesis, in contrast, posits that competition enhances stability. We refer to Beck et al. (2013) for an overview of the literature on bank competition and stability as well as conditional correlations between bank market power and stability for 79 countries.

${ }^{2}$ In April 2015, a resolution put forward by two Dutch politicians was adopted to investigate ways of easing and facilitating switching on the premise that competition will increase if switching is made easier. In July 2016 the National Forum on the Payment System published a statement on improving customer mobility urging parties in the payments market to improve efforts to enhance mobility and thereby foster competition (NFPS 2016b).

${ }^{3}$ The European Commission (2006) reports that some EU countries define relevant product markets based on individual products.
} 
product, what are the most important factors explaining variation in switching propensities? iv) How effective are (potential) policies to lower switching barriers and/or increase (the threat of) switching?

We focus on consumers' reported propensities to switch, collected from survey data. In the remainder of the paper we simply call these "propensities to switch". To answer the second research question, we use insights from studies in different industries to identify a broad range of factors that may be related to consumers' propensity to switch banks in the coming year. ${ }^{4}$ The factors we study are perceived benefits of switching, personal characteristics, switching experience, socio-psychological factors, the bank-customer relationship and knowledge related to banking products.

Better knowledge of factors related to switching propensities, switching barriers, and the effectiveness of potential policies is important for policymakers who want to increase (the threat of) switching. One way to increase competition is to allow new foreign banks to enter the market. Consequently it is also key for policymakers to understand how consumers respond to new foreign players.

Although we research bank switching behaviour of consumers in the Netherlands, the questions apply broadly to other countries as well. In all countries there should be a threat of consumers leaving their bank to foster competition. Consequently insight in factors related to switching and ways to strengthen the threat of switching is of general interest. Besides, switching rates are comparable across the Netherlands, other European countries and the US. ${ }^{5}$

We find that the propensity to switch depends on the banking product. The propensity to switch is highest for consumers' main savings accounts. We also find that the main factors explaining the propensity to switch best depend on the banking product. Differences in the propensity to switch the main current account are best explained by differences in the strength of the bank-customer relationship and socio-psychological factors. The bank-customer relationship is also the most important factor for the propensity to switch main savings accounts. In contrast, switching experiences play the most important role in explaining variation in the propensity to switch mortgage loans. One of our study's key insights is therefore that it is important to examine banking products separately. Our findings are meaningful for antitrust policy. Instead of using a legal standard for analysing competition that is based on clustering, our findings provide an argument in favour of using a product market definition that is highly disaggregated.

In addition, we report that satisfaction with the current situation is the most important reason to stay at one's bank. The general perception that switching is a hassle, that there is nothing to gain, and the absence of account number portability are also reasons why a substantial proportion of bank customers do not switch.

Regarding the effectiveness of potential policies to increase (the threat of) switching, we find that the reported propensity to switch main current accounts can be increased by introducing account number portability. Improving knowledge of the switching service has no significant effect. To examine respondents' willingness to switch to a new domestic or foreign bank, we randomly divide respondents in four groups and present each group with a

\footnotetext{
${ }^{4}$ E.g. the car insurance industry (Antón et al. 2007), landline telecom, home insurance, electricity industry (Gamble et al. 2009; Ek and Söderholm 2008) and the banking sector (i.e. Kiser 2002).

${ }^{5}$ Research by the European Commission (2012) shows that $10 \%$ of the current account holders switched the last five years in The Netherlands, while on average $8 \%$ of consumers switched in EU27 countries in the same period. $11 \%$ of the North Americans switched to a new financial service provider during March 2015 and March 2016 (Accenture 2016). Note that this proportion does not only include switching with the current account. As a result, it is not surprising that the switching proportion is higher.
} 
different scenario. Based on these scenarios we find that it is especially difficult for new foreign banks to attract savings in the Netherlands. Therefore, a policy aiming at attracting new domestic players seems to be more effective in enhancing mobility than a policy that increases the number of foreign players.

The remainder of the paper is organized as follows: Section 2 provides an overview of the literature. Section 3 describes the survey, switching propensities and barriers that withhold people from switching. Section 4 presents the methodology and shows our estimation results. Section 5 examines the effectiveness of hypothetical policies to increase (the threat of) switching and Section 6 presents our conclusions.

\section{Literature}

The literature on relationship banking explains that building a relationship with the bank can be beneficial for customers. During the relationship, the bank privately observes information about the customer which can foster flexibility in loan contracts (Boot and Thakor 1994; Von Thadden 1995) and favorable contract terms for the customers (e.g. lower interest rates or less collateral). However, at the same time there are also costs associated with relationship banking. Banks can extract rents as the inside bank has an informational advantage over competing banks (Ioannidou and Ongena 2010). Consequently, the customer is locked-in. This effect will be more pronounced when consumers face switching costs. Switching costs may withhold customers from switching which blocks efficient buyer-selling matching (Farrell and Klemperer 2007).

Few studies empirically examine consumer bank switching behaviour and although consumers hold different banking products with distinct characteristics, these studies focus on the main bank. Kiser (2002) finds that geographic stability is an important factor for having a long-term relationship with the main bank, that switchers are more likely to be "shoppers" who compare prices, and that there is a cohort effect rather than an age effect involved in switching in the US. Chakravarty et al. (2004) address consumers' propensity to switch and find that personal characteristics are important in explaining switching intentions. Responsiveness, empathy, reliability and relationship duration are significantly negatively related to the propensity to switch, while having experienced problems with the bank positively impacts the propensity to switch. A recent paper from Brunetti et al. (2016) relates the bank-customer relationship to actual switching behaviour using Italian data from 2006 to 2012. The results show that having a relationship with only one bank and having more services with the main bank reduce the propensity to switch. Using Japanese data, Inakura and Shimizutani (2010) investigate the relationship between deposit insurance and bank switching. Respondents who had no knowledge of a change in the deposit insurance cap were less likely to actually switch and also more likely to not consider switching.

Research on switching in other markets also reveals potentially relevant factors. Antón et al. (2007) focus on switching intentions in the car-insurance industry. They find that the perception of unfair prices and experience of anger incidents have more capacity to explain switching intentions than quality and the organisation's commitment. Focusing on the electricity market, Ek and Söderholm (2008) show that income and education positively impact the intention to switch. Moreover, they find that perceptions about the behaviour of others, social descriptive norms, affect switching intentions. Gamble et al. (2009) study attitudes towards switching within three deregulated markets in Sweden characterised by a homogenous product: electricity, landline telecom, and home insurance. They find that loyalty has a negative effect on the attitude towards switching. 
To summarize, the literature on switching emphasises the role of personal characteristics, the bank-customer relationship, knowledge and socio-psychological variables in explaining switching behaviour. This is why we investigate the role of these factors in explaining differences in switching propensities.

We expect to find differences in the propensity to switch across banking products. We predict the propensity to switch to be highest for savings accounts as new accounts are opened quickly, often without costs, and savings are easily transferred to the new account. Consumers who already have more than one savings account, may just transfer their savings to an existing account. We anticipate that the propensity to switch the main current account is lower as it is less easy to switch. Current accounts are often linked to other banking products and if customers switch banks they need to inform others about the new account number. Because of high evaluation and monetary costs we expect the propensity to switch mortgage loans to be lower. Besides, consumers are not always able to obtain a loan at another bank (supply effect). As a result we also expect a lower propensity to switch for revolving credit.

Our research questions not only contribute to the academic literature, they may also yield important implications for policymaking. Differences in switching propensities and the main related factors would provide an argument in favour of using a legal standard for the analysis of competition that is not based on clustering. Amel et al. (2008) explain that the current legal standard for analysing competition in the US views banking markets as geographically local and considers the cluster of financial products. The use of the cluster of banking services has generated less commentary than the use of local geographic banking markets. Both regulators and potential bank acquirers find the use of clusters convenient. The European Commission (2006) also reports that it focuses on retail banking markets as a whole in merger decisions. Without the clustering, antitrust analyses would become more time-consuming and costly. Our study contributes to the discussion on whether products should be considered as being in separate markets.

\section{Survey}

\subsection{Data}

We conducted a survey among the CentERpanel, a representative sample of the Dutchspeaking population in the Netherlands, in June 2015. ${ }^{6}$ For each banking product we investigate the propensity that someone will switch to another bank in the upcoming 12 months. The survey also includes questions on past switching behaviour, the bank-customer relationship, barriers that withhold consumers from switching, requirements that a new bank should meet and socio-psychological statements and policies that try to alleviate switching barriers and/or increase (the threat of) switching. ${ }^{7}$

\footnotetext{
${ }^{6}$ The Dutch banking sector is characterized by its size and level of concentration. In Europe, only Greece, Estonia, Lithuania and Finland have a more concentrated banking system (DNB 2015b).

${ }^{7}$ A stumbling block withholding people from switching banks is the time and effort it takes to arrange the switch. To alleviate this burden, in 2004 the Netherlands was the first country to instigate a "switching service" to facilitate switching current accounts. Specifically, it ensures that payments are transferred automatically to the new account for a period of 13 months, and it verifies that direct debits are paid from the new bank account. It also provides an overview of all transferred transactions. Consumers still need to inform others about the new account numbers.
} 
The survey was sent out to 2693 members of the CentERpanel and completed by 2194 respondents, which represents an $81.5 \%$ response rate. ${ }^{8,9}$ For some questions the response rate is higher (up to $83.1 \%$ ) as 44 panellists partially completed the questionnaire. We merge the survey data with data on personal characteristics from the annual DNB Household Survey (DHS). This survey is filled in by the same respondents, and exists for more than two decades. ${ }^{10}$ CentERdata, a research institute affiliated to Tilburg University, manages the CentERpanel. ${ }^{11}$

\subsection{Background information on banking products}

The banking products we study are the main current account, savings account, mortgage loan and revolving credit. Around $70 \%$ of adults had exactly one current account in 2013 , while the average number of accounts is 1.16 (Gfk 2014). The current account acts a gateway for other products. As a result the majority of consumers have their current account and deposits at the same bank (Gfk 2014). As in many other European countries, bank customers pay a fee for having a current account, ranging between EUR 14.40 and EUR 180 per year (Consumentenbond 2016). However, more than half of consumers are not aware of the costs involved (Gfk 2014).

The majority of savings are held at instant-access accounts rather than at term deposits (Competition \& Markets Authority 2015b). Interest rates on savings accounts are generally higher in the Netherlands than in surrounding countries, where small Dutch banks offer 50 basis points higher interest rates than large Dutch banks (ACM, 2014). Savings up to EUR 100,000 deposited at almost all banks active in the Netherlands are guaranteed by the European Deposit Guarantee Scheme.

Around $30 \%$ of total lending in the Netherlands is in the form of outstanding mortgage loans to households (Competition \& Markets Authority 2015b). It is common to have a high loan-to-value ratio due to incentives as the tax relief and the national mortgage guarantee. Between 2010 and 2015 the proportion of households choosing a period of long-term fixed interest rate has increased. In 2015, $68 \%$ of the households chose a fixed interest period of at least five years, which was likely to be driven by the low interest rates (DNB 2016).

The average amount of revolving credit was approximately EUR 8000 in 2013 (CEG 2014). Interest rates for revolving credit are generally lower than for overdrafts. The number and total amount of revolving credit has decreased between 2010 and 2013 (CBS 2017).

\subsection{The propensity to switch by banking product}

Depending on whether they hold the relevant product, we asked survey participants: "What is the propensity that you will switch within the next twelve months with your main [current account/savings account/mortgage loan/revolving credit]? Fill in a propensity between 0 and

\footnotetext{
${ }_{8}^{8}$ The questionnaire is available on request.

${ }^{9}$ For more information on the CentERpanel, see Teppa and Vis (2012) and http://www.centerdata.nl/en/projectsby-centerdata/origins-of-the-centerpanel. URL last accessed on 10 April 2017.

${ }^{10}$ Information on the DHS is available at http://www.centerdata.n1/en/projects-by-centerdata/dnb-householdsurvey-dhs. URL last accessed on 10 April 2017.

${ }^{11}$ Previous researchers and policymakers have used the CentERpanel to investigate and ask questions on a broad range of topics. For example, Hurd et al. (2011) investigate stock market expectations, Von Gaudecker (2015) examines households' portfolio diversification, Georgarakos et al. (2014) research the impact of social interactions on debt and Van der Cruijsen et al. (2012) study the impact of crisis experiences on savings behaviour.
} 
$100\left(0 \%=\right.$ 'I will definitely not switch' and 100\% = 'I will definitely switch')". ${ }^{12}$ We prefer to focus on switching propensities rather than yes/no intention questions as Juster (1966) shows in his seminal paper that elicited purchase probabilities are better predictors of subsequent behaviour. ${ }^{13}$ Note that we measure switching between banks. Our interest in switching from one bank to another bank is clarified in the introduction of our questionnaire. Second, we use the Dutch word 'overstappen', which is used for switching from one company to another. A bank-related example of the use of this word is that the service that helps consumers switch banks is called the 'overstapservice'.

We find that the propensity to switch in the coming year indeed depends on the product in question. Figure 1 shows that the average propensity to switch is the lowest for main revolving credits $(5.7 \%)$ and mortgage loans $(6.4 \%)$, slightly higher for main current accounts $(6.8 \%)$ and the highest for main savings accounts (10.2\%). This indicates differences between consumers' assets and liabilities. ${ }^{14}$ The share of respondents who will definitely not switch is high; it ranges from $62.1 \%$ for savings accounts to $74.3 \%$ for revolving credits. For each banking product, the proportion of consumers who definitely intend to switch is below $1 \% .{ }^{15}$

The data supports our first hypothesis, which states that the propensity to switch depends on the banking product. Based on t-tests, we find that the propensity to switch savings accounts is significantly higher than the propensity to switch current accounts, mortgage loans and revolving credits (all $p=0.00$ ). Focusing on individuals, paired t-tests show that respondents report a significantly higher propensity to switch their main savings accounts than their main current accounts $(p=0.00)$ and main mortgage loans $(p=0.00) .{ }^{16}$ Table 5 in Appendix 1 reports the results of the paired t-tests.

We find positive and significant correlations between switching propensities (in all cases $p=0.00$ ). The correlation is the strongest between the propensity to switch the main current account and the propensity to switch the main revolving credit $(0.68)$. The propensity to switch the main savings account and the propensity to switch the main mortgage loan are the least correlated $(0.25)$.

\subsection{Discussion of barriers}

Figure 2 gives an overview of potential switching barriers. The figure shows the answers to the question "There can be different factors withholding you from switching. How important are

\footnotetext{
${ }^{12}$ An often expressed concern is whether respondents are able to answer questions about propensities. The CentERpanel is experienced in answering such questions and therefore we believe that the respondents understand the question and are able to answer it. CentERdata has checked the clarity of our survey.

${ }^{13}$ We refer to Manski (2004) for an overview of the evolution of the literature on probabilistic expectations.

${ }^{14}$ Fischhoff and Bruine de Bruin (1999) indicate that a recorded value of 50\% might mean that respondents have no idea (epistemic uncertainty) rather than that they record a quantitative probability. We think this is not a major issue in our case. First, as mentioned before, members of the CentERpanel are used to answering propensity questions. Second, our question clearly indicates what $0 \%$ and $100 \%$ answers mean. Third, for all banking products, only a small proportion of respondents express a propensity to switch of exactly $50 \%$ (ranging from $4.4 \%$ for current accounts to $7.6 \%$ for savings accounts).

${ }^{15}$ Based on survey data collected in February 2014 Gfk concludes that $3 \%$ of respondents actually switched banks with their main current account in the last 12 months (Gfk 2014). There is no research on bank switching behaviour that examines the gap between intentions and actual behaviour. However, in other fields it is shown that intentions matter for actual behaviour. Other factors are important too. A meta-analysis by Webb and Sheeran (2006) shows that a medium-to-large change in intention results in a small-to-medium change in behaviour.

${ }^{16}$ Paired t-tests compare for the same individual the propensity to switch across products. Consequently the sample is restricted to respondents who have multiple banking products.
} 


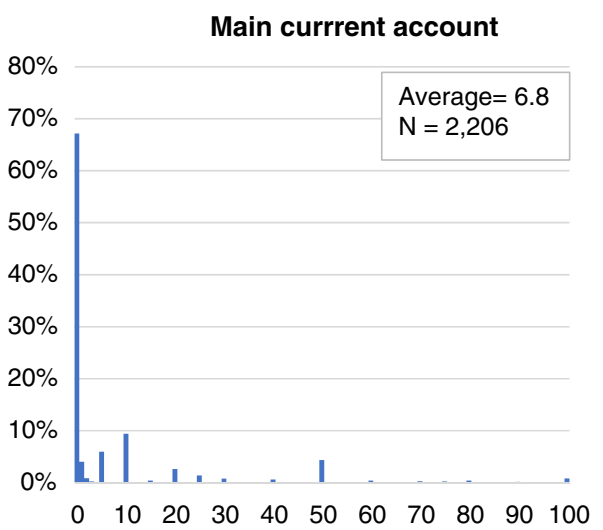

Main savings account

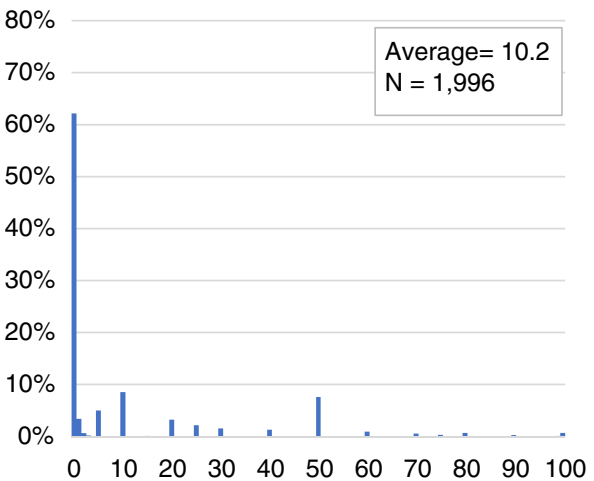

Main mortgage loan
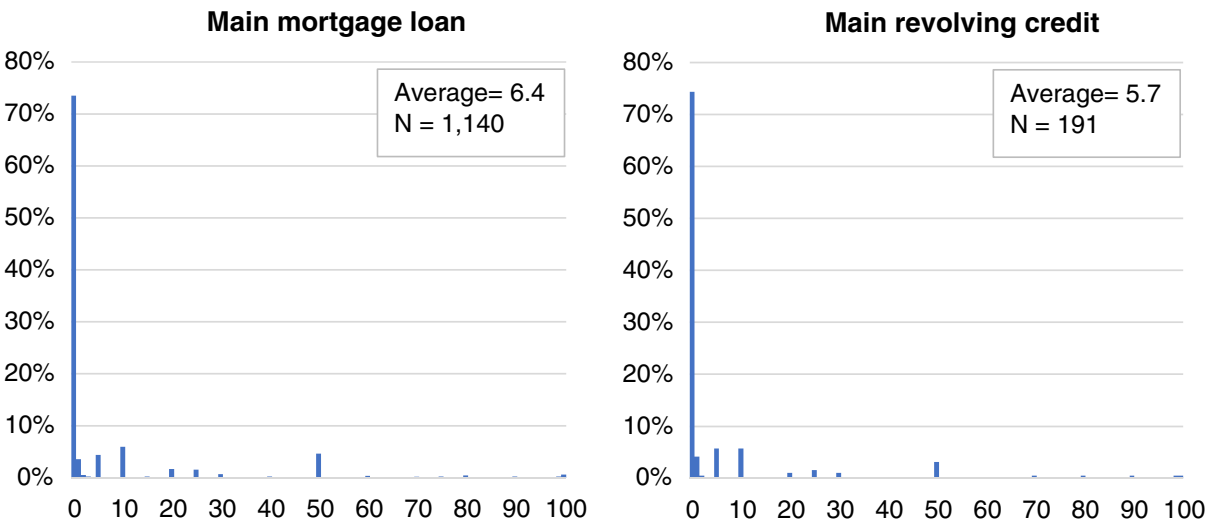

Fig. 1 Propensity to switch in the next twelve months. Source: CentERpanel, June 2015. Note: This figure also shows the switching propensities of respondents who did not complete the whole survey. 44 respondents started the survey but did not finish it

the factors below?" The statements are unconditional, and therefore we measure the importance of each barrier at this moment, rather than the importance if it were a barrier.

We find that for three out of four respondents, satisfaction with the current situation is a very or extremely important factor why people stay at their bank. Other relationship characteristics, like having a long-standing bank-customer relationship and finding it difficult to trust another bank also withhold a substantial group of respondents from switching. A large number of respondents mention that there is not much to gain from switching.

The outcomes also indicate important practical barriers. About half of the respondents state that the absence of account number portability withholds them from switching. A significant proportion of respondents also find switching a hassle and believe that it costs a lot of time and money. A substantial share of respondents find it a difficult choice and are afraid of making the wrong decision.

Table 6 in Appendix 2 looks at differences in the importance of barriers between respondents who will definitely not switch (switching propensity $p_{p}=0$ ) and respondents who are considering switching in the coming year (switching propensity $p_{p}>0$ ). Regarding all products, we find that for respondents who are considering switching, the relationship with their bank is a less important barrier than it is for respondents who will definitely stay with their current 
1. I am satisfied with the current situation.

2. There is not much benefit from switching.

3. I cannot keep my account number(s).

4. It is a hassle to switch.

5. I am customer of this/these bank(s) for along time.

6. I find it difficult to judge the benefit of switching.

7. It costs a lot of time to arrange a switch.

8. I find it difficult to trust another bank.

9. It costs a lot of money to switch.

10. It is a difficult choice.

11. I am afraid to make the wrong choice.

12. There are not enough banks to choose from.

13. It is difficult to switch because of other banking products.

14. There are too many banks to choose from.

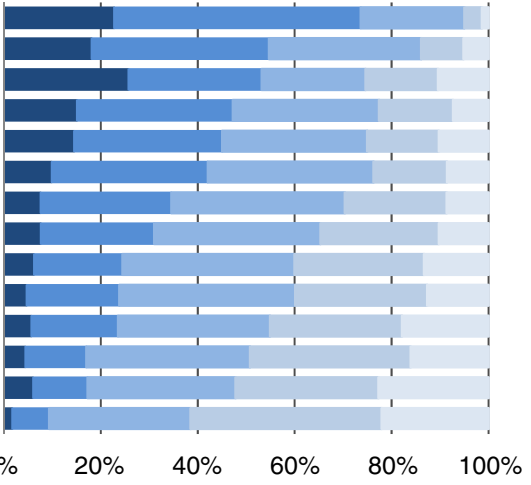

Extremely important factor

Not a very important factor

- Very important factor

Somewhat important factor

Fig. 2 Barriers to switching. Source: CentERpanel, June 2015. Note: The figure shows the response shares to the question "There can be different factors withholding you from switching. How important are the factors below?" Factors are ranked based on the average answer

bank. Respondents considering switching their current account find the absence of account number portability, lack of time and insufficient banks to choose from more important barriers than respondents who will definitely not switch their current accounts. The same holds for savings accounts. We clearly find that respondents who report a positive propensity to switch their main mortgage loans (switching propensity mortgage loan $>0$ ) perceive the long bankcustomer relationship less a barrier than other respondents (switching propensity mortgage loan $=0$ ) do.

\section{Propensity to switch: regressions}

\subsection{Methodology}

We research the decision to switch banks for each product separately to test whether the variables related to the propensity to switch depend on the banking product. We also examine which factors are most important in explaining variation in switching propensities of the individual banking products. Table 1 shows the estimated coefficients of Tobit regressions, where each column represents the switching propensity of a specific banking product: current account (column 1), savings account (column 2), mortgage loan (column 3), and revolving credit (column 4). The dependent variables are the reported propensities to switch banks within the next twelve months (expressed as a percentage). Scores for these dependent variables range between 0 and 100. A large proportion of the observations are at the 0 boundary. Therefore these are corner solution variables and we use the Tobit model. ${ }^{17}$

\footnotetext{
${ }^{17}$ Wooldridge (2002) argues that it makes sense to call the model that fits this type of data well a corner solution model. However, in practice the term censored regression model is used more often. Wooldridge (2002) argues that a suited method to use for a corner solution dependent variable is the Tobit model (Papalia and Di Iorio 2001). In general, most of our findings are robust with respect to the chosen method.
} 
Table 1 Propensity to switch by banking product: baseline regressions

\begin{tabular}{|c|c|c|c|c|}
\hline & $\begin{array}{l}\text { Current } \\
\text { account }\end{array}$ & $\begin{array}{l}\text { Savings } \\
\text { account }\end{array}$ & $\begin{array}{l}\text { Mortgage } \\
\text { loan }\end{array}$ & $\begin{array}{l}\text { Revolving } \\
\text { credit }\end{array}$ \\
\hline Male & $\begin{array}{l}0.10 \\
(2.10)\end{array}$ & $\begin{array}{l}-1.27 \\
(2.39)\end{array}$ & $\begin{array}{l}1.83 \\
(4.13)\end{array}$ & $\begin{array}{l}-1.23 \\
(9.56)\end{array}$ \\
\hline Between 35 and 44 & $\begin{array}{l}-0.10 \\
(3.43)\end{array}$ & $\begin{array}{l}1.49 \\
(3.93)\end{array}$ & $\begin{array}{l}-12.79 * \\
(6.64)\end{array}$ & $\begin{array}{l}18.81 \\
(18.05)\end{array}$ \\
\hline Between 45 and 54 & $\begin{array}{l}1.59 \\
(3.42)\end{array}$ & $\begin{array}{l}1.08 \\
(3.92)\end{array}$ & $\begin{array}{l}-9.83 \\
(6.89)\end{array}$ & $\begin{array}{l}24.92 \\
(19.17)\end{array}$ \\
\hline Between 55 and 64 & $\begin{array}{l}-4.05 \\
(3.47)\end{array}$ & $\begin{array}{l}-8.02 * * \\
(3.97)\end{array}$ & $\begin{array}{l}-25.85 * * * \\
(7.01)\end{array}$ & $\begin{array}{l}-7.21 \\
(16.38)\end{array}$ \\
\hline 65 and over & $\begin{array}{l}-15.10 * * * \\
(3.33)\end{array}$ & $\begin{array}{l}-17.86^{* * * *} \\
(3.79)\end{array}$ & $\begin{array}{l}-27.08 * * * \\
(7.15)\end{array}$ & $\begin{array}{l}7.44 \\
(16.87)\end{array}$ \\
\hline Education: bachelor degree or higher & $\begin{array}{l}4.76^{* *} \\
(2.08)\end{array}$ & $\begin{array}{l}4.50^{*} \\
(2.34)\end{array}$ & $\begin{array}{l}-6.84 * \\
(3.76)\end{array}$ & $\begin{array}{l}-2.18 \\
(8.14)\end{array}$ \\
\hline Income category & $\begin{array}{l}-0.17 \\
(0.40)\end{array}$ & $\begin{array}{l}0.40 \\
(0.44)\end{array}$ & $\begin{array}{l}2.23 * * * \\
(0.79)\end{array}$ & $\begin{array}{l}-1.94 \\
(1.69)\end{array}$ \\
\hline Degree of urbanisation & $\begin{array}{l}1.40^{*} \\
(0.74)\end{array}$ & $\begin{array}{l}0.92 \\
(0.81)\end{array}$ & $\begin{array}{l}1.03 \\
(1.36)\end{array}$ & $\begin{array}{l}6.65 * * \\
(3.32)\end{array}$ \\
\hline Responsible for household finances & $\begin{array}{l}1.81 \\
(2.11)\end{array}$ & $\begin{array}{l}0.85 \\
(2.44)\end{array}$ & $\begin{array}{l}0.74 \\
(4.02)\end{array}$ & $\begin{array}{l}25.36 * * \\
(9.97)\end{array}$ \\
\hline Not much benefit of switching & $\begin{array}{l}-5.02 * * * \\
(0.95)\end{array}$ & $\begin{array}{l}-1.21 \\
(1.03)\end{array}$ & $\begin{array}{l}-2.27 \\
(1.74)\end{array}$ & $\begin{array}{l}-7.24^{*} \\
(3.94)\end{array}$ \\
\hline Recent switching experience $_{p}$ & $\begin{array}{l}47.52 * * \\
(18.58)\end{array}$ & $\begin{array}{l}23.58 * * * \\
(5.84)\end{array}$ & $\begin{array}{l}-11.90 \\
(13.19)\end{array}$ & $\begin{array}{l}6.98 \\
(13.88)\end{array}$ \\
\hline Older switching experience ${ }_{p}$ & $\begin{array}{l}1.97 \\
(2.42)\end{array}$ & $\begin{array}{l}9.60 * * * \\
(2.64)\end{array}$ & $\begin{array}{l}16.07 * * * \\
(3.84)\end{array}$ & $\begin{array}{l}12.43 \\
(8.82)\end{array}$ \\
\hline Other switching experience ${ }_{p}$ & $\begin{array}{l}3.96^{*} \\
(2.35)\end{array}$ & $\begin{array}{l}-1.48 \\
(2.63)\end{array}$ & $\begin{array}{l}8.25^{* * *} \\
(3.54)\end{array}$ & $\begin{array}{l}-3.96 \\
(8.11)\end{array}$ \\
\hline Customer loyalty $_{p}$ & $\begin{array}{l}-6.79 * * * \\
(0.97)\end{array}$ & $\begin{array}{l}-7.87 * * * \\
(1.04)\end{array}$ & $\begin{array}{l}-4.33 * * * \\
(1.52)\end{array}$ & $\begin{array}{l}0.06 \\
(3.67)\end{array}$ \\
\hline Number of banks & $\begin{array}{l}0.57 \\
(1.01)\end{array}$ & $\begin{array}{l}3.83 * * * \\
(1.15)\end{array}$ & $\begin{array}{l}1.94 \\
(1.78)\end{array}$ & $\begin{array}{l}6.69 \\
(5.26)\end{array}$ \\
\hline Filed a complaint & $\begin{array}{l}14.49 * * * \\
(3.40)\end{array}$ & $\begin{array}{l}17.19 * * * \\
(3.85)\end{array}$ & $\begin{array}{l}-0.49 \\
(5.60)\end{array}$ & $\begin{array}{l}7.14 \\
(12.35)\end{array}$ \\
\hline Knowledge of banking product ${ }_{p}$ & $\begin{array}{l}-1.41 \\
(2.00)\end{array}$ & $\begin{array}{l}9.25 * * * \\
(2.49)\end{array}$ & $\begin{array}{l}1.75 \\
(4.65)\end{array}$ & $\begin{array}{l}3.59 \\
(8.81)\end{array}$ \\
\hline Knowledge of other banking products ${ }_{p}$ & $\begin{array}{l}8.94 * * \\
(4.25)\end{array}$ & $\begin{array}{l}-9.76^{* *} \\
(4.60)\end{array}$ & $\begin{array}{l}-21.14 * * * \\
(7.79)\end{array}$ & $\begin{array}{l}4.25 \\
(14.18)\end{array}$ \\
\hline Knowledge of switching service & $\begin{array}{l}-0.31 \\
(1.23)\end{array}$ & & & \\
\hline $\begin{array}{l}\text { Knowledge of switching service * } \\
\text { Recent switching experience } \\
\text { current account }\end{array}$ & $\begin{array}{l}-23.30 * * * \\
(7.88)\end{array}$ & & & \\
\hline Knowledge of Deposit Guarantee Scheme & & $\begin{array}{l}5.36^{*} \\
(2.76)\end{array}$ & & \\
\hline Perceived control over switching & $\begin{array}{l}5.87 * * * \\
(1.23)\end{array}$ & $\begin{array}{l}4.33 * * * \\
(1.32)\end{array}$ & $\begin{array}{l}2.20 \\
(2.25)\end{array}$ & $\begin{array}{l}5.64 \\
(4.50)\end{array}$ \\
\hline Degree to which switching is unpleasant & $\begin{array}{l}0.25 \\
(1.11)\end{array}$ & $\begin{array}{l}0.08 \\
(1.22)\end{array}$ & $\begin{array}{l}-2.95 \\
(1.96)\end{array}$ & $\begin{array}{l}8.53^{*} \\
(4.45)\end{array}$ \\
\hline Injunctive social norms & $\begin{array}{l}5.54 * * * \\
(1.41)\end{array}$ & $\begin{array}{l}2.23 \\
(1.55)\end{array}$ & $\begin{array}{l}0.67 \\
(2.25)\end{array}$ & $\begin{array}{l}0.81 \\
(5.59)\end{array}$ \\
\hline Perceived switching behaviour of others & $\begin{array}{l}1.52 \\
(1.23)\end{array}$ & $\begin{array}{l}2.15 \\
(1.37)\end{array}$ & $\begin{array}{l}-0.66 \\
(2.07)\end{array}$ & $\begin{array}{l}0.43 \\
(4.32)\end{array}$ \\
\hline Jointly owned banking product & $\begin{array}{l}2.18 \\
(1.96)\end{array}$ & $\begin{array}{l}1.52 \\
(2.24)\end{array}$ & $\begin{array}{l}-3.65 \\
(4.19)\end{array}$ & $\begin{array}{l}20.22 * * \\
(9.79)\end{array}$ \\
\hline Constant & $\begin{array}{l}-27.45 * * * \\
(9.42)\end{array}$ & $\begin{array}{l}-32.07 * * * \\
(10.13)\end{array}$ & $\begin{array}{l}-6.81 \\
(16.08)\end{array}$ & $\begin{array}{l}-123.32 * * * \\
(41.05)\end{array}$ \\
\hline Observations & 2086 & 1889 & 1087 & 181 \\
\hline
\end{tabular}

This table reports parameter estimates for Tobit regressions. Robust standard errors are in parentheses. The equations are estimated together to allow individual-level errors to be correlated. Variables with subscript $p$ vary per regression. Subscript $p$ indicates the banking product. *** $p<0.01, * * p<0.05, * p<0.1$ 
We relate the propensity to switch to potentially relevant factors and postulate that:

$$
\text { Switching propensity }=\left\{\begin{array}{cl}
\text { switching propensity }_{\text {ip }}^{*} & \text { if } 0<\text { switching propensity }_{\text {ip }}^{*}<100 \\
0 & \text { if switching propensity } \\
\text { ip } \leq 0 \\
100 & \text { if switching propensity }
\end{array}\right.
$$

where switching propensity ${ }_{i p}^{*}$ is the latent variable:

$$
\text { switching propensity }{ }_{i p}^{*}=\beta_{1} X_{i}+\beta_{2} B_{i p}+\beta_{3} E_{i p}+\beta_{4} R_{i p}+\beta_{5} K_{i p}+\beta_{6} S_{i p}+e_{i p}
$$

In these equations, $i$ denotes the individual and $p$ the banking product. We estimate the equations together and allow individual-level errors to be correlated. The vector $\mathrm{X}$ captures personal characteristics. We include a binary dummy male that is 1 for males and 0 for females. Four binary age dummies capture the age: between 35 and 44, between 45 and 54, between 55 and 64 and 65 and over. The reference category consists of people aged 34 or below. The level of education is measured by including the binary dummy variable education: bachelor degree or higher. We furthermore include income category which captures the gross monthly personal income. Switching propensities may also depend on respondents' place of residence. We therefore include degree of urbanisation, which ranges between 1 (rural) and 5 (very urbanised). The last variable included in $\mathrm{X}$ is responsible for household finances, which is a binary dummy that is 1 for respondents who take care of household finances.

As shown in Fig. 1 a large proportion of respondents report a switching propensity of $0 \%$. A potential concern is that these zeros are generated by two distinct data generation processes. Either one foresees no incentive to switch and reports a propensity of $0 \%$, or one foresees an incentive to switch but nevertheless does not intend to do so (for example because one finds it a hassle). To distinguish between the two cases, we control for perceived benefits of switching by including not much benefit of switching (vector B). This variable ranges between 1 (strongly disagree) and 5 (strongly agree).

Third, the vector E includes both recent and non-recent switching experience with the banking product in question, as well as switching experience with other banking products. For each banking product, we construct three binary dummy variables: recent switching experience, older switching experience and other switching experience. Recent switching experience is 1 for respondents who switched less than a year ago with the banking product in question, whereas older switching experience is 1 for respondents who switched at least a year ago with this product. For respondents who have at any point switched with other banking products, other switching experience is set at 1 . For all banking products, we find that the vast majority of respondents have never switched banks, a substantial proportion switched longer than a year ago, and only a small proportion report recent switching activities. For revolving credit, we find the highest proportion of respondents without switching experience (73\%), whereas the highest proportion of respondents reporting switching experience is for mortgage loans (44\%).

Fourth, the vector $\mathrm{R}$ captures the strength of the bank-customer relationship. The first variable customer loyalty measures the perceived strength of the relationship. This variable ranges between 1 (no bond at all) and 5 (very strong bond) and is measured separately for each banking product. Many respondents report having a strong bank-customer relationship. We include number of banks, which is a measure of the number of banks. We find that $43 \%$ of 
respondents bank with one bank only. Lastly, we construct the binary dummy filed a complaint that is 1 for consumers who filed a complaint in the three years prior to the survey.

Fifth, we include a vector $\mathrm{K}$ with product specific knowledge variables. For the current account we include a binary dummy that is 1 for respondents who report to know how much they pay for their main current account including debit cards. We also include knowledge of switching service, a variable that measures the extent to which one is familiar with the switching service. For the other three banking products we include binary dummies that capture selfreported knowledge of the interest rate. For the savings account we also construct knowledge of Deposit Guarantee Scheme, a binary dummy that is 1 for respondents who state that they know the DGS. In each regression, we also include a variable that captures the knowledge of other banking products. We find that a substantial proportion of bank customers are not fully aware of the costs and benefits of banking products, the switching service and the DGS. ${ }^{18}$

Sixth, the vector $\mathrm{S}$ includes a range of socio-psychological variables that measure the degree of perceived control over switching, joint ownership of the product, social norms (injunctive social norms and perceived switching behaviour of others), and the extent to which consumers perceive switching as unpleasant. Almost one in five respondents believes that they would not be able to switch if they would want to. We find that joint ownership is the lowest for main current accounts (52\% of respondents) and the highest for the main mortgage loans (77\% of respondents). Only a small proportion of consumers believe that others whom they want to resemble switch every now and then, and that people who are important to them think they should switch. $50 \%$ of the respondents perceive switching as unpleasant. Appendix 3 includes a detailed description of the variables that we constructed and the summary statistics.

\subsection{Results}

We find that the model provides a better fit than an intercept-only model for the main current account, savings account and mortgage loan (F-test, $p=0.00) .{ }^{19}$ The regression model of revolving credit is not significant (F-test, $p=0.40$ ) so we will not discuss these results.

A wide range of variables from all six factors significantly explains variation in switching propensities, and both the sign and significance level of these variables depend on the banking product in question. Although we do not necessarily identify causal effects, our regressions reveal interesting correlations.

First of all, we find that the propensity to switch is significantly related to various socioeconomic variables. There is a negative age effect for all three products. For example, the predicted propensity to switch the current accounts is $9.1 \%$ for people aged 34 or below and $4.8 \%$ for people in the highest age bracket. ${ }^{20}$ This negative age effect is in line with studies on switching in banking and health insurance (Chakravarty et al. 2004; Inakura and Shimizutani 2010; Frank and Lamiraud 2009).

\footnotetext{
${ }^{18}$ This finding is related to the results of Van der Cruijsen et al. (2011), who show that consumers gather little information on the bank and product before choosing a savings product.

${ }^{19}$ Note that multicollinearity is not a problem in our regressions. The mean Variance Inflation Factor (VIF) ranges between 1.48 and 1.99. The minimum VIF found is 1.05 and the maximum is 5.08. As a rule of thumb a VIF smaller than 10 is fine.

${ }^{20}$ To obtain the predicted propensity to switch the current account, we make a prediction for every respondent while setting the variable 65 and over at 1 and the other age dummies at 0 . The average of these predictions is the predicted propensity to switch for respondent aged 65 or above. All predictions below zero are set to 0 and all predictions above 100 are set to 100 .
} 
In addition, people with a high degree of education are more likely to switch their main current account and savings account than people without a bachelor degree or higher. The opposite holds for the propensity to switch mortgage loans. Income is positively related to the reported propensity to switch the main mortgage loan provider.

We also find that consumers living in urbanised regions are more likely to switch their current account than consumers in rural areas. A plausible explanation is that some consumers find it important to have a physical bank branch nearby. However, in the Netherlands there are fewer banks in rural areas than in urbanised regions and the distance to the closest bank branch is further (National Forum on the Payment System 2016a). To the extent that this is causing the lower switching propensity in rural areas, it provides an argument in favour of preserving local bank branches in rural areas or improving online banking if one wants to strengthen (the threat of) switching. This finding is in line with Brunetti et al. (2016) who report a negative effect of bank market concentration on switching.

As in Chakravarty et al. (2004), Ek and Söderholm (2008) and Brunetti et al. (2016) we do not find a gender effect. There is also no difference between people who are responsible for household finances and those who are not.

Second, switching propensities are related to the perceived benefits of switching. This relationship is significant for the current account. The predicted propensity of switching is $9.9 \%$ for people who disagree with the statement that there is not much benefit from switching, and $6.6 \%$ for people who agree with this statement.

Third, we confirm the positive relationship between switching experience and the propensity to switch documented in Chakravarty et al. (2004). The predicted propensity of switching main savings accounts in the coming year is $20.8 \%$ for consumers with recent experience, whereas it is $9.9 \%$ for consumers who did not switch these accounts in the past year. Regarding main current accounts, we also find that consumers who switched less than a year ago report a higher propensity to switch in the coming year. This effect is stronger for people unfamiliar with the switching service. For mortgage loans it is not the recent experience that counts, but the experience of having switched more than a year ago. This is intuitive given the long maturity of mortgage loans and the switching penalty. Experience in switching other banking products also matters for current accounts and mortgage loans. ${ }^{21}$

Fourth, switching propensities are related to the strength of the bank-customer relationship. In the case of all banking products, consumers who feel a strong bond with their bank report a significantly lower propensity to switch than respondents who feel a weak bond or no bond at all. To illustrate the strength of the effect, the predicted propensity to switch their main current account is $9.3 \%$ for consumers who feel a poor bond with the bank where they hold their main current account, whereas it is only $5.2 \%$ for consumers who feel a strong bond. We furthermore find a positive relationship between the number of bank-customer relationships and the reported propensity to switch main savings accounts. This is in line with Brunetti et al. (2016) who report a positive relationship between having multiple bank relationships and switching the main bank in general. In addition, we find that consumers who contacted their bank in the

\footnotetext{
${ }^{21}$ We cannot rule out the possibility that an omitted variable explains both switching experience and switching propensities. Furthermore, in case of knowledge there may be reverse causality or an omitted factor driving both knowledge and switching propensities. We ran additional regressions excluding experience and knowledge. Our findings are robust. We find the same variables to be related to switching propensities as in the baseline analysis, with two exceptions: (1) perceived switching behaviour of others is significantly positive related to the propensity to switch savings, and (2) between 35 and 44 is no longer significantly related to the propensity to switch mortgages. The results are available upon request.
} 
past three years to file a complaint report a significantly higher propensity to switch main current and savings accounts than consumers without complaints.

Fifth, switching propensities are also related to knowledge of banking products. The propensity to switch savings accounts is higher for consumers who know by heart the interest rate they currently receive than for other consumers. The predicted propensity to switch is $11.5 \%$ for the first group and $8.3 \%$ for the second group. This finding is in line with Van der Cruijsen et al. (2012) who show that consumers who consider themselves knowledgeable about financial matters are more likely to have savings accounts at multiple banks. Knowledge of the DGS is positively related to the propensity to switch main savings accounts. Compared to the effects of other variables in the model, this effect is rather small. The difference in the predicted switching probability is 1.9 percentage points. Knowledge of other banking products has a mixed effect on the propensity to switch. The effect is positive for the main current account but negative for the main savings account and mortgage loan.

Lastly, the propensity to switch is also related to socio-psychological factors. Consumers who agree with the statement "If I want, I can switch to another bank" are more likely to switch their main current account and savings account than consumers who disagree with this statement. For example, with respect to the current account we find that people who strongly agree with this statement have a predicted propensity to switch of $9.2 \%$, while the predicted propensity to switch for people who neither agree nor disagree with this statement is $5.6 \%$. We also find that consumers who agree with the statement that switching is unpleasant are less likely to switch their main mortgage provider than consumers who disagree with this statement. In addition, injunctive social norms significantly relate to the propensity to switch current accounts. The predicted propensity is $7.5 \%$ for consumers who disagree with the statement "I believe that most people who are important to me think that I should switch to another bank" and $11.5 \%$ for consumers who agree with this statement. Perceptions of the behaviour of people who one wants to resemble do not significantly matter. This is in contrast to findings of Ek and Söderholm (2008) who report that behaviour of others positively affects switching electricity suppliers in Sweden. Lastly, we find that the propensity to switch is the same for people with joint banking products and single users.

In short, we conclude that for all banking products a wide range of factors are related to the reported propensities to switch the current account, savings account and mortgage loan and that the strength of the relationships depend on the banking product. For all three banking products, we find that personal characteristics, the strength of the bank-customer relationship, switching experience, and knowledge of banking products are related to the propensity to switch. In addition, perceived benefits are related to the propensity to switch the current account and socio-psychological factors matter for both the propensity to switch the current account and savings account.

To examine the importance of each of the six factors of our model, we regress switching propensities on the variables belonging to each of the six factors of our model separately and measure the relative quality of the models by assessing Akaike's Information Criterion (AIC, Akaike 1974). The results are presented in Appendix 4.

The most important factors related to switching propensities depend on the banking product. The bank-customer relationship is most important in explaining variation in the propensity to switch current accounts, followed by socio-psychological factors. The bankcustomer relationship is also the main factor explaining the propensity to switch savings accounts. This finding is in line with studies that show that the bank-customer relationship is important in financial decision making (Brunetti et al. 2016; Brown et al. 2016). Switching 
experience is the second most important factor for the savings account and the most important factor for mortgage accounts. The factor that ranks second in explaining variation in mortgage loan switching propensities is personal characteristics. ${ }^{22}$

\subsection{Robustness}

As a first robustness test, we present the outcomes of regressions which excludes all respondents who state that "satisfaction with the current situation" is an extremely important factor that withholds them from switching. Although unforeseen circumstances may trigger a switch, the incentive to switch and the reported propensities to switch are lower for this group of respondents than for other respondents. Table 2 presents the regression results. Overall, we find that most of our results are robust to the exclusion of respondents with the weakest incentive to switch. There are only a few coefficients that have become insignificant: education: bachelor degree or higher in case of the savings account regression, and between 35 and 44 and income category in the mortgage loan regression.

Second, as responses are skewed we make bin switching probabilities (0-20 20-40, 40-60, 60-80 and 80-100) and estimate ordered logits and find that most of our baseline results are robust. $^{23}$ There are a few exceptions. For the current account switching propensities are no longer related to education: bachelor or higher, other switching experience and knowledge of other banking products. Regarding the savings account, we now find insignificant coefficients for between 55 and 64, education: bachelor degree or higher, knowledge of other banking products and knowledge of DGS. We do find a significant coefficient for injunctive social norms now. With respect to switching propensities for mortgage loans we find significant coefficients for not much benefit of switching and degree to which switching is unpleasant, and an insignificant coefficient for other switching experience. Moreover, this robustness exercise tells us that the size of the effects we found in our baseline analysis are plausible, and it confirms that the strength of the relationships can be substantial. ${ }^{24,25}$

Third, we add background variables distilled from DNB's annual Household Survey. The number of observations is substantially lower in these cases because these background characteristics are not available for all participants in our survey. As a first exercise, we include risk aversion and find a negative relationship between the level of risk aversion and the propensity to switch for all banking products. Most other relationships still hold. ${ }^{26}$ Additional robustness analyses show no significant relationship between self-assessed financial knowledge or change in relative trust in the bank and the propensity to switch. For revolving credit the model becomes significant if we add the variables risk aversion, self-

\footnotetext{
${ }^{22}$ We do not discuss the outcomes for the propensity to switch for the main revolving credit as all models are insignificant. The results are available upon request.

23 The results of all robustness analyses are available upon request.

${ }^{24}$ For example, the strong effect of switching experience is confirmed. Compared to people without recent switching experience, people with recent switching experience are 16 percentage points less likely to report a switching propensity between $0 \%$ and $20 \%, 4$ percentage points more likely to report a switching propensity between $20 \%$ and $40 \%, 8$ percentage points more likely to report a switching propensity between $40 \%$ and $60 \%$, and 2 percentage points more likely to report a switching propensity between $60 \%$ and $80 \%$ or between $80 \%$ and $100 \%$.

${ }^{25}$ As additional robustness tests we have also estimated (1) Tobit regressions with log-transformed dependent variables, and (2) fractional response logit models. The results of the robustness analyses are available on request. ${ }^{26}$ Education: bachelor degree or higher is no longer significant for the current and savings account. Between 45 and 54 and knowledge DGS lose significance in the specification of the main savings account. Between 45 and 54 is now significant in the specification of mortgage loans.
} 
Table 2 Propensity to switch by banking product: excluding extremely satisfied customers

\begin{tabular}{|c|c|c|c|c|}
\hline & $\begin{array}{l}\text { Current } \\
\text { account }\end{array}$ & $\begin{array}{l}\text { Savings } \\
\text { account }\end{array}$ & $\begin{array}{l}\text { Mortgage } \\
\text { loan }\end{array}$ & $\begin{array}{l}\text { Revolving } \\
\text { credit }\end{array}$ \\
\hline Male & $\begin{array}{l}-1.25 \\
(2.29)\end{array}$ & $\begin{array}{l}-3.25 \\
(2.60)\end{array}$ & $\begin{array}{l}5.55 \\
(4.36)\end{array}$ & $\begin{array}{l}3.84 \\
(11.53)\end{array}$ \\
\hline Between 35 and 44 & $\begin{array}{l}-0.48 \\
(3.70)\end{array}$ & $\begin{array}{l}1.55 \\
(4.34)\end{array}$ & $\begin{array}{l}-9.98 \\
(6.86)\end{array}$ & $\begin{array}{l}13.61 \\
(26.07)\end{array}$ \\
\hline Between 45 and 54 & $\begin{array}{l}0.72 \\
(3.61)\end{array}$ & $\begin{array}{l}0.67 \\
(4.18)\end{array}$ & $\begin{array}{l}-9.13 \\
(7.15)\end{array}$ & $\begin{array}{l}23.88 \\
(26.95)\end{array}$ \\
\hline Between 55 and 64 & $\begin{array}{l}-5.49 \\
(3.73)\end{array}$ & $\begin{array}{l}-8.01 * \\
(4.35)\end{array}$ & $\begin{array}{l}-23.74 * * * \\
(7.15)\end{array}$ & $\begin{array}{l}-12.10 \\
(24.41)\end{array}$ \\
\hline 65 and over & $\begin{array}{l}-15.52 * * * \\
(3.58)\end{array}$ & $\begin{array}{l}-18.14 * * * \\
(4.15)\end{array}$ & $\begin{array}{l}-25.74 * * * \\
(7.39)\end{array}$ & $\begin{array}{l}-1.36 \\
(25.23)\end{array}$ \\
\hline Education: bachelor degree or higher & $\begin{array}{l}4.38^{*} \\
(2.27)\end{array}$ & $\begin{array}{l}3.77 \\
(2.56)\end{array}$ & $\begin{array}{l}-7.66^{*} \\
(4.08)\end{array}$ & $\begin{array}{l}-8.76 \\
(10.36)\end{array}$ \\
\hline Income category & $\begin{array}{l}-0.11 \\
(0.43)\end{array}$ & $\begin{array}{l}0.42 \\
(0.48)\end{array}$ & $\begin{array}{l}1.33 \\
(0.85)\end{array}$ & $\begin{array}{l}-2.11 \\
(1.92)\end{array}$ \\
\hline Degree of urbanisation & $\begin{array}{l}1.78^{* *} \\
(0.81)\end{array}$ & $\begin{array}{l}1.04 \\
(0.88)\end{array}$ & $\begin{array}{l}0.79 \\
(1.47)\end{array}$ & $\begin{array}{l}6.76^{*} \\
(3.82)\end{array}$ \\
\hline Responsible for household finances & $\begin{array}{l}1.27 \\
(2.29)\end{array}$ & $\begin{array}{l}1.54 \\
(2.65)\end{array}$ & $\begin{array}{l}1.11 \\
(4.28)\end{array}$ & $\begin{array}{l}23.74 * * \\
(10.97)\end{array}$ \\
\hline Not much benefit of switching & $\begin{array}{l}-4.94 * * * \\
(1.11)\end{array}$ & $\begin{array}{l}-0.36 \\
(1.22)\end{array}$ & $\begin{array}{l}-0.68 \\
(2.06)\end{array}$ & $\begin{array}{l}-6.59 \\
(4.57)\end{array}$ \\
\hline Recent switching experience $_{\mathrm{p}}$ & $\begin{array}{l}41.27^{*} \\
(21.51)\end{array}$ & $\begin{array}{l}24.23 * * * \\
(6.28)\end{array}$ & $\begin{array}{l}-13.24 \\
(16.00)\end{array}$ & $\begin{array}{l}7.55 \\
(14.13)\end{array}$ \\
\hline Older switching experience $e_{\mathrm{p}}$ & $\begin{array}{l}2.20 \\
(2.60)\end{array}$ & $\begin{array}{l}6.81 * * \\
(2.85)\end{array}$ & $\begin{array}{l}17.63 * * * \\
(4.06)\end{array}$ & $\begin{array}{l}7.45 \\
(11.71)\end{array}$ \\
\hline Other switching experience $e_{\mathrm{p}}$ & $\begin{array}{l}3.98 \\
(2.47)\end{array}$ & $\begin{array}{l}0.70 \\
(2.80)\end{array}$ & $\begin{array}{l}7.56^{* * *} \\
(3.75)\end{array}$ & $\begin{array}{l}1.59 \\
(10.25)\end{array}$ \\
\hline Customer loyalty $_{\mathrm{p}}$ & $\begin{array}{l}-5.06^{* * *} \\
(1.07)\end{array}$ & $\begin{array}{l}-6.49 * * * \\
(1.16)\end{array}$ & $\begin{array}{l}-2.98 * \\
(1.67)\end{array}$ & $\begin{array}{l}2.28 \\
(4.41)\end{array}$ \\
\hline Number of banks & $\begin{array}{l}0.10 \\
(1.10)\end{array}$ & $\begin{array}{l}2.11^{*} \\
(1.28)\end{array}$ & $\begin{array}{l}2.82 \\
(1.97)\end{array}$ & $\begin{array}{l}5.28 \\
(5.53)\end{array}$ \\
\hline Filed a complaint & $\begin{array}{l}14.59 * * * \\
(3.54)\end{array}$ & $\begin{array}{l}16.77 * * * \\
(4.03)\end{array}$ & $\begin{array}{l}2.07 \\
(5.81)\end{array}$ & $\begin{array}{l}-14.03 \\
(18.89)\end{array}$ \\
\hline Knowledge of banking product ${ }_{p}$ & $\begin{array}{l}-1.68 \\
(2.14)\end{array}$ & $\begin{array}{l}10.58 * * * \\
(2.68)\end{array}$ & $\begin{array}{l}3.33 \\
(4.80)\end{array}$ & $\begin{array}{l}13.77 \\
(11.34)\end{array}$ \\
\hline Knowledge of other banking products ${ }_{p}$ & $\begin{array}{l}10.71 * * \\
(4.53)\end{array}$ & $\begin{array}{l}-9.51^{*} \\
(5.03)\end{array}$ & $\begin{array}{l}-18.92 * * \\
(8.06)\end{array}$ & $\begin{array}{l}0.65 \\
(18.33)\end{array}$ \\
\hline Knowledge of switching service & $\begin{array}{l}-0.77 \\
(1.33)\end{array}$ & & & \\
\hline $\begin{array}{l}\text { Knowledge of switching service * } \\
\text { Recent switching experience } \\
\text { current account }\end{array}$ & $\begin{array}{l}-21.49 * * \\
(9.49)\end{array}$ & & & \\
\hline Knowledge of Deposit Guarantee Scheme & & $\begin{array}{l}5.99 * * \\
(3.05)\end{array}$ & & \\
\hline Perceived control over switching & $\begin{array}{l}7.02 * * * \\
(1.42)\end{array}$ & $\begin{array}{l}5.47 * * * \\
(1.57)\end{array}$ & $\begin{array}{l}2.22 \\
(2.59)\end{array}$ & $\begin{array}{l}3.39 \\
(5.43)\end{array}$ \\
\hline Degree to which switching is unpleasant & $\begin{array}{l}0.37 \\
(1.26)\end{array}$ & $\begin{array}{l}0.13 \\
(1.40)\end{array}$ & $\begin{array}{l}-1.44 \\
(2.22)\end{array}$ & $\begin{array}{l}8.55 \\
(5.57)\end{array}$ \\
\hline Injunctive social norms & $\begin{array}{l}5.28 * * * \\
(1.60)\end{array}$ & $\begin{array}{l}1.66 \\
(1.77)\end{array}$ & $\begin{array}{l}1.78 \\
(2.51)\end{array}$ & $\begin{array}{l}6.47 \\
(6.51)\end{array}$ \\
\hline Perceived switching behaviour of others & $\begin{array}{l}0.67 \\
(1.40)\end{array}$ & $\begin{array}{l}1.66 \\
(1.57)\end{array}$ & $\begin{array}{l}-2.10 \\
(2.23)\end{array}$ & $\begin{array}{l}-4.19 \\
(5.55)\end{array}$ \\
\hline Jointly owned banking product ${ }_{p}$ & $\begin{array}{l}3.46 \\
(2.14)\end{array}$ & $\begin{array}{l}1.82 \\
(2.46)\end{array}$ & $\begin{array}{c}-0.01 \\
(4.54)\end{array}$ & $\begin{array}{l}31.78^{* * * *} \\
(11.37)\end{array}$ \\
\hline Constant & $\begin{array}{l}-31.50 * * * \\
(10.61)\end{array}$ & $\begin{array}{l}-36.11 * * * \\
(11.44)\end{array}$ & $\begin{array}{l}-23.38 \\
(18.08)\end{array}$ & $\begin{array}{l}-125.64 * * \\
(51.44)\end{array}$ \\
\hline Observations & 1609 & 1447 & 846 & 139 \\
\hline
\end{tabular}

This table reports parameter estimates for Tobit regressions. The sample excludes respondents who indicate that satisfaction with the current situation is an extremely important factor that withholds them from switching and respondents who do not report the degree of satisfaction. Robust standard errors are in parentheses. The equations are estimated together to allow individual-level errors to be correlated. Variables with subscript $p$ vary per regression. Subscript $p$ indicates the banking product. $* * * p<0.01, * * p<0.05, * p<0.1$ 
assessed knowledge or change in relative trust. Consumers who believe that their financial knowledge is adequate are less likely to switch their main revolving credit than consumers who perceive their knowledge to be poor.

The balance on the main savings account is positively related to the propensity to switch this account. A variable that measures to what extent people save with the goal to generate interest income is not significantly related to the propensity to switch the savings account. The value of the mortgage loan has a positive but insignificant sign if included in the regression with the mortgage switching propensity. We do not find a significant effect on the propensity to switch of a year-on-year change in the trust in one's own bank compared to other banks.

Fourth, we take into account whether customers have different types of banking products at the same bank. Brown et al. (2016) report that customers are less likely to withdraw from a distressed bank when they have a loan linkage with this bank. In the specification of current accounts we include two dummy variables representing whether one has a mortgage loan and/or a savings account. We do not find a significant difference in the propensity to switch between consumers with a mortgage and/or a savings account and consumers without these accounts. To guarantee that the savings account and mortgage loan are held at the same bank as the current account, we restrict the sample to respondents who bank with only one bank in a next specification. Again we do not find significant effects for having a savings account or a mortgage loan.

\section{Effectiveness of policies to increase (the threat of) switching}

In this section, we address the last research question by discussing the effectiveness of three different hypothetical policies to increase (the threat of) switching: attracting new foreign banks, increasing knowledge of the switching service and introducing account number portability.

\subsection{Attracting new banks}

A first potential way to increase (the threat of) switching is to enhance the benefits of switching by allowing new banks to enter the market. For this policy to be effective, customers should be willing to switch to new banks, which can either be domestic or foreign. Six out of ten of our respondents indicate they are not willing to switch to a foreign bank. ${ }^{27}$ To examine this issue in more detail, we perform a scenario analysis for the savings account.

This scenario analysis confirms that it will be more difficult for new foreign banks than new domestic banks to attract new customers. A policy of allowing new foreign banks to enter the savings market is less promising for enhancing mobility than a policy that increases the number of domestic players. Table 3 shows the outcomes of the four cases. Respondents were randomly assigned to one of these. The question was: "Suppose you have a savings account with a balance of EUR 25,000 at a Dutch

\footnotetext{
${ }^{27}$ Previous studies have shown that consumers prefer domestic products. For more information on this topic see Siamagka and Balabanis (2015).
} 
Table 3 Home bias in bank switching behaviour

\begin{tabular}{|c|c|c|c|c|c|c|c|c|}
\hline & $\begin{array}{l}\text { Deposit } \\
\text { insurance } \\
\text { text }\end{array}$ & $\begin{array}{l}\text { Certainly } \\
\text { not }\end{array}$ & $\begin{array}{l}\text { Probably } \\
\text { not }\end{array}$ & Neutral & $\begin{array}{l}\text { Probably } \\
\text { yes }\end{array}$ & $\begin{array}{l}\text { Certainly } \\
\text { yes }\end{array}$ & $\begin{array}{l}\text { Mean } \\
\text { score }\end{array}$ & $\mathrm{N}$ \\
\hline Dutch bank & no & $8 \%$ & $25 \%$ & $33 \%$ & $28 \%$ & $7 \%$ & 3 & 564 \\
\hline Foreign bank & no & $26 \%$ & $39 \%$ & $21 \%$ & $13 \%$ & $1 \%$ & 2.2 & 577 \\
\hline Difference & & $-18 \%$ & $-15 \%$ & $12 \%$ & $15 \%$ & $6 \%$ & $0.8 * * *$ & \\
\hline Dutch bank & yes & $7 \%$ & $21 \%$ & $27 \%$ & $35 \%$ & $10 \%$ & 3.2 & 536 \\
\hline Foreign bank & yes & $22 \%$ & $31 \%$ & $23 \%$ & $19 \%$ & $5 \%$ & 2.5 & 522 \\
\hline Difference & & $-15 \%$ & $-11 \%$ & $5 \%$ & $16 \%$ & $5 \%$ & $0.7 * * *$ & \\
\hline
\end{tabular}

Source: CentERpanel, June 2015

The question was: "Suppose you have a savings account with a balance of EUR 25,000 at a Dutch bank. You receive $1 \%$ interest on your savings (EUR 250 per year). A new [Dutch/foreign] bank, Bank B, enters the market and offers $2 \%$ interest (EUR 500 per year). [If the bank goes bankrupt, you will get your money back.] Would you switch?" $\mathrm{N}=$ number of respondents. $* * * p<0.01$

bank. You receive $1 \%$ interest on your savings (EUR 250 per year). A new [Dutch/ foreign] bank, Bank B, enters the market and offers 2\% interest (EUR 500 per year). [If the bank goes bankrupt, you will get your money back.] Would you switch?" Respondents indicated the propensity to switch to a new entrant that offers a higher interest rate for savings. Depending on the scenario, the new entrant was either a Dutch or a foreign bank and the accompanying text included the line "If the bank goes bankrupt, you will get your money back" or not. Table 3 shows that consumers are significantly less likely to switch to a foreign bank than to a Dutch bank. Respondents who received the scenario with the text "If the bank goes bankrupt, you will get your money back" report a significantly higher propensity to switch than respondents who received the question without this text $(p<0.01)$. However, there remains a significant difference in the propensity to switch to domestic and foreign banks. ${ }^{28}$

\subsection{Increasing knowledge of the switching service}

A second route to enhance (the threat of) switching is by better informing customers of the "switching service". This service was introduced in the Netherlands in 2004 to make current account switching easier. The service ensures that payments are automatically transferred to the new account for 13 months after the switch and that direct debits are paid from the new bank account. It also provides an overview of all transferred transactions. ${ }^{29}$ However, not all consumers are aware of the switching service. To test the impact of better knowledge of the switching service on the reported switching propensities, we informed respondents about this service. After this explanation respondents who reported that they did not know of this service, or did not know exactly know what it entails, were again asked to report their switching

\footnotetext{
${ }^{28}$ Note that in these scenarios consumers know the ultimate owner of the bank, while in practice not all consumers may know whether their bank is foreign or domestically owned.

${ }^{29}$ Although the switching service provides a framework to facilitate switching, customers need to inform third parties about their new account numbers.
} 
propensity. We find that on average the reported switching propensity is not significantly higher after the explanation, see Table $4 .^{30}$

\subsection{Reducing the hassle: account number portability}

The last potential policy to increase (the threat of) switching that we examine is introducing account number portability. Although the switching service makes switching easier, customers still have to inform third parties of their new account number. Account number portability does not currently exist but would enable account holders to retain their current account numbers when switching to a new bank. Although account number portability would not eliminate all aspects of switching costs, Table 4 reveals that the average reported propensity to switch significantly increases in the hypothetical case of number portability. The effect is the strongest for respondents who are aware of what the switching service provides. ${ }^{31}$ More research is needed to evaluate whether the benefits of account number portability outweigh the costs involved due to technical complexity and to learn to what extent consumers' attitudes change if they have to pay for account number portability.

\section{Conclusions}

Policymakers argue for more competition in the banking sector to improve efficiency of banking services. However, consumer inertia can impose a barrier for new entrants and can lower competition among current players (ACM, 2014). Despite its relevance, little is known about consumers' switching behaviour.

This paper provides detailed insight into consumers' bank switching behaviour. Although our research focuses on the Netherlands, the questions we raise apply broadly to other countries as well. By conducting a survey among a representative panel of consumers, we retrieve a unique dataset that enables us to study switching intentions, barriers to switching, factors related to switching intentions and the effectiveness of hypothetical policy initiatives to ease switching.

We contribute to the existing literature in several ways. First, we show that the propensity to switch differs across banking products, with the propensity to switch the main savings account to be highest. Second, we provide insight in barriers that withhold consumers from switching. Satisfaction with the current situation is the most often mentioned reason for staying at one's

\footnotetext{
${ }_{30}$ The question was: "The switching service entails that the first thirteen months after switching to another bank, payments are automatically redirected to your new current account. Payments based on direct debit will be directly withdrawn from your new account. In addition, your statement of account includes an overview of all redirected transactions. You also have to arrange some things yourself, for example applying for a debit card, credit card and online banking at the new bank and informing people and companies that pay money into your account about your new account number. You indicated a likelihood of switching within 12 months with your main current account of $x \%$. What is the likelihood that you will switch within 12 months with your main current account now that you know (more) about the switching service? Fill in a percentage between 0 and $100(0 \%=$ "I will certainly not switch" and $100 \%=$ "I will certainly switch")."

${ }^{31}$ The question was formulated as follows: "Currently, if you want to switch your current account you can't keep your current account number. Account number portability means that bank customers can keep their current account number when they switch banks. You indicated a likelihood of switching within 12 months your main current account of $x \%$. What is the likelihood that you will switch within 12 months your main current account if you were able to keep the account number? Fill in a percentage between 0 and $100(0 \%=$ "I will certainly not switch" and $100 \%=$ "I will certainly switch")."
} 
Table 4 Effectiveness of improving knowledge and reducing hassle

\begin{tabular}{|c|c|c|c|c|c|}
\hline & \multirow[t]{2}{*}{$\begin{array}{l}\text { Average switching } \\
\text { propensity (in \%) }\end{array}$} & \multicolumn{3}{|c|}{$\begin{array}{l}\text { Percentage of respondents } \\
\text { who report a switching } \\
\text { propensity of... }\end{array}$} & \multirow[t]{2}{*}{$\mathrm{N}$} \\
\hline & & $\ldots 0 \%$. & $\ldots 100 \%$ & $\ldots \geq 50 \%$ & \\
\hline \multicolumn{6}{|l|}{ All respondents } \\
\hline Current situation & 6.8 & 67.1 & 0.8 & 6.7 & 2206 \\
\hline $\begin{array}{l}\text { In case of account number portability after } \\
\text { explanation switching service }\end{array}$ & $13.3 * * *$ & 58.1 & 2.3 & 13.7 & 2205 \\
\hline \multicolumn{6}{|l|}{ People unaware of the switching service } \\
\hline Current situation & 5.8 & 70.4 & 0.6 & 5.6 & 895 \\
\hline After explanation of switching service & 7.0 & 66.4 & 0.6 & 6.1 & 895 \\
\hline $\begin{array}{l}\text { After explanation and account number } \\
\text { portability }\end{array}$ & $10.7 * * *$ & 62.9 & 1.3 & 10.8 & 895 \\
\hline \multicolumn{6}{|c|}{ People unaware of the content of the switching service } \\
\hline Current situation & 8.0 & 60.9 & 0.6 & 8.3 & 654 \\
\hline After explanation of switching service & 8.9 & 56.9 & 0.5 & 8.4 & 654 \\
\hline $\begin{array}{l}\text { After explanation and account number } \\
\text { portability }\end{array}$ & $15.8 * * *$ & 48.9 & 1.8 & 15.0 & 654 \\
\hline \multicolumn{6}{|c|}{ People aware of the content of the switching service } \\
\hline Current situation & 7.0 & 68.9 & 1.4 & 6.7 & 657 \\
\hline $\begin{array}{l}\text { In case of account number portability after } \\
\text { explanation switching service }\end{array}$ & $14.4 * * *$ & 60.7 & 4.1 & 16.2 & 656 \\
\hline
\end{tabular}

Source: CentERpanel, June 2015

This table shows the reported propensity that someone will switch within twelve months with their main current account before and after the switching service was explained to them. It also shows the effect of the hypothetical case of account number portability on the reported propensity to switch. $\mathrm{N}=$ the number of respondents. We have tested whether the difference in reported switching probablities is significant. $* * * p<0.01$

bank. The perceptions that switching is a hassle, that there is nothing to gain, and the absence of account number portability are also withholding a substantial proportion of respondents from actually switching.

Third, we reveal that a wide range of variables is related to switching propensities, and that both the sign and significance level of these variables depend on the banking product in question. Consumers' differences in the propensity to switch their main current accounts are best explained by differences in the strength of the bank-customer relationship and sociopsychological factors. The bank-customer relationship is also the most important factor for the propensity to switch their main savings accounts. In contrast, switching experiences play the most important role explaining variations in the propensity to switch mortgage loans.

One of the key policy implications of our research is that it is important to view banking products separately. This finding gives guidance for designing antitrust policy. It provides an argument against using a legal standard for the analysis of competition that is based on clustering, as is done by the Federal Reserve (2014) and European Commission (2006), and in favour of using a product market definition that is highly disaggregated.

Another finding with potential policy implications is that local banking competition matters for the current account. Consumers living in urbanised regions are more likely to switch their current account than consumers in rural areas. A plausible explanation is that some consumers find it important to have a physical bank branch nearby and there are fewer banks in rural areas (National 
Forum on the Payment System 2016a). To the extent that this is causing the lower switching propensity in rural areas, it provides an argument in favour of preserving local bank branches in rural areas or improving online banking if one wants to strengthen (the threat of) switching.

Last, we show the effectiveness of potential policies to increase (the threat of) switching, thereby providing policymakers with initial guidelines. We find that consumers are less willing to switch their savings account to a new foreign bank than to a new domestic bank. This suggests that a policy of allowing new foreign banks to enter the savings market is less promising in enhancing mobility than a policy that increases the number of domestic players. Regarding the main current account, our research indicates that reported switching propensities do not significantly change as a result of better knowledge of the switching service. We also test the hypothetical effect of account number portability. Introducing account number portability seems to be a more promising policy avenue.

We will leave it to future research to provide insight into time patterns and to what extent various events and technological developments, such as the increase in electronic banking, affect switching behaviour. We also welcome studies that include non-banks in the analysis, given the rise of non-banks executing banking activities, e.g. credit unions providing loans and technology companies providing payment services. It would also be interesting to analyse the gap between switching propensities and actual switching behaviour.

Acknowledgements We thank three anonymous referees for careful reading of the manuscript and their feedback and suggestions. We are furthermore grateful for discussions with Yvonne Adema, Marieke Bos, Hans Brits, Jakob de Haan, David-Jan Jansen, Olivier De Jonghe, Nicole Jonker, Rein Kieviet, Joris Knoben, Maarten van Rooij, Helmut Stix, Ayse Zoodsma and seminar participants at Tilburg University, the Netherlands Economist Day, De Nederlandsche Bank, the DNB Payments Conference 2016, the IBEFA summer meeting 2016, the 15th TIBER Symposium on Psychology and Economics and the Research in Behavioral Finance Conference 2016. We thank Miquelle Marchand (CentERdata) for arranging the survey and Gareth Budden and Renée Dekker for linguistic services. The views expressed in this paper do not necessarily reflect the views of De Nederlandsche Bank or those of the Eurosystem.

\section{Appendix 1. Comparison of switching propensities}

Table 5 Paired t-tests to compare reported switching propensities across banking products

\begin{tabular}{lrcrrr}
\hline & Average switching propensity (in \%) & Difference & t-value & $P$-value & $\mathrm{N}$ \\
\hline Main current account & 6.7 & -3.51 & -10.20 & 0.00 & 1988 \\
Main savings account & 10.3 & & & & \\
Main current account & 7.3 & 0.90 & 1.52 & 0.13 & 1138 \\
Main mortgage loan & 6.4 & & & & \\
Main current account & 6.4 & 0.65 & 0.65 & 0.51 & \\
Main revolving credit & 5.8 & & & & \\
Main savings account & 11.4 & 4.97 & 6.89 & 0.00 & 1074 \\
Main mortgage loan & 6.4 & & & & \\
Main savings account & 8.0 & 1.74 & 1.26 & 0.21 & 164 \\
Main revolving credit & 6.3 & -1.37 & -0.79 & 0.43 & 128 \\
Main mortgage loan & 5.4 & & & & \\
Main revolving credit & 6.8 & & & & \\
\hline
\end{tabular}

This table shows the results of paired t-tests. The column "difference" shows the difference in average switching propensity for the products in question. The column "t-value" shows the t-value of testing whether the difference is equal to zero, while the column " $p$-value" reports the according $p$-value of this test. $\mathrm{N}$ denotes the number of observations 


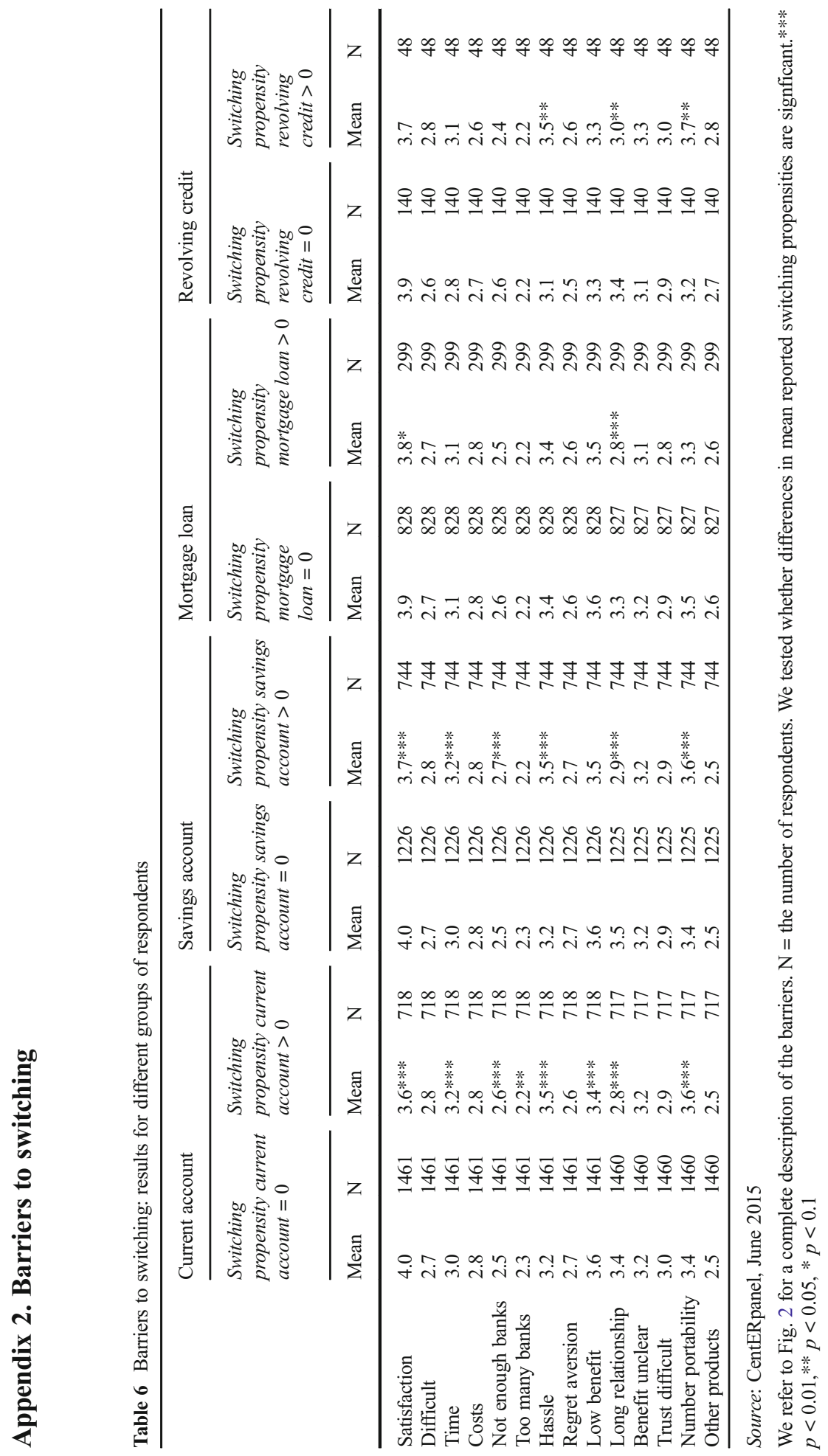




\section{Appendix 3. Description of variables}

Table 7 Description of variables

\begin{tabular}{|c|c|c|c|c|c|c|}
\hline Variable & Description & Mean & $\mathrm{Sd}$ & Min & Max & $\mathrm{N}$ \\
\hline \multicolumn{7}{|l|}{ Dependent variables } \\
\hline $\begin{array}{l}\text { Switching propensity current } \\
\text { account }\end{array}$ & $\begin{array}{l}\text { Propensity to switch within the next } \\
\text { twelve months with main current } \\
\text { account }(\%) \text {. }\end{array}$ & 6.68 & 16.54 & 0 & 100 & 2086 \\
\hline $\begin{array}{l}\text { Switching propensity savings } \\
\text { account }\end{array}$ & $\begin{array}{l}\text { Propensity to switch within the next } \\
\text { twelve months with main savings } \\
\text { account }(\%) \text {. }\end{array}$ & 9.98 & 19.79 & 0 & 100 & 1889 \\
\hline $\begin{array}{l}\text { Switching propensity } \\
\text { mortgage loan }\end{array}$ & $\begin{array}{l}\text { Propensity to switch within the next } \\
\text { twelve months with main mortgage } \\
\text { loan }(\%) \text {. }\end{array}$ & 6.34 & 17.03 & 0 & 100 & 1087 \\
\hline $\begin{array}{l}\text { Switching propensity } \\
\text { revolving credit }\end{array}$ & $\begin{array}{l}\text { Propensity to switch within the next } \\
\text { twelve months with main revolving } \\
\text { credit }(\%) \text {. }\end{array}$ & 5.85 & 17.15 & 0 & 100 & 181 \\
\hline \multicolumn{7}{|l|}{ Personal characteristics $(\mathrm{X})$} \\
\hline Male & Binary dummy ( $1=$ male, $0=$ female $)$. & 0.53 & 0.50 & 0 & 1 & 2093 \\
\hline 34 and below & $\begin{array}{l}\text { Binary dummy }(1=34 \text { or below, } 0= \\
\text { else). }\end{array}$ & 0.11 & 0.31 & 0 & 1 & 2093 \\
\hline Between 35 and 44 & $\begin{array}{l}\text { Binary dummy ( } 1=\text { between } 35 \text { and } 44,0 \\
\quad=\text { else). }\end{array}$ & 0.17 & 0.38 & 0 & 1 & 2093 \\
\hline Between 45 and 54 & $\begin{array}{l}\text { Binary dummy ( } 1=\text { between } 45 \text { and } 54,0 \\
=\text { else). }\end{array}$ & 0.16 & 0.37 & 0 & 1 & 2093 \\
\hline Between 55 and 64 & $\begin{array}{l}\text { Binary dummy ( } 1=\text { between } 55 \text { and } 64,0 \\
\quad=\text { else). }\end{array}$ & 0.22 & 0.41 & 0 & 1 & 2093 \\
\hline 65 and over & Binary dummy $(1=65$ or older, $0=$ else $)$ & 0.34 & 0.47 & 0 & 1 & 2093 \\
\hline $\begin{array}{l}\text { Education: bachelor degree } \\
\text { or higher }\end{array}$ & $\begin{array}{l}\text { Successful completion of higher } \\
\text { vocational education and/or university } \\
\text { education. Binary dummy }(1= \\
\text { graduate level diploma, } 0=\text { else }) \text {. }\end{array}$ & 0.37 & 0.48 & 0 & 1 & 2093 \\
\hline Income category & $\begin{array}{l}\text { Classification of gross monthly personal } \\
\text { income in euros }(1=500 \text { or less, } 2= \\
501-1000,3=1001-1500,4= \\
1501-2000,5=2001-2500,6= \\
2501-3000,7=3001-3500,8= \\
3501-4000,9=4001-4500,10= \\
4501-5000,11=5001-7500,12= \\
7500 \text { or more })\end{array}$ & 4.96 & 2.80 & 1 & 12 & 2093 \\
\hline Degree of urbanisation & $\begin{array}{l}\text { Degree of urbanisation of respondent's } \\
\text { residence based on the address density } \\
\text { per } \mathrm{km}^{2}(1=500 \text { or less, } 2= \\
500-1000,3=1000-1500,4= \\
1500-2500,5=\text { more than } 2500)\end{array}$ & 2.94 & 1.31 & 1 & 5 & 2093 \\
\hline $\begin{array}{l}\text { Responsible for household } \\
\text { finances }\end{array}$ & $\begin{array}{l}\text { Whether or not respondent is responsible } \\
\text { for the household's financial affairs. } \\
\text { Binary dummy }(1=\text { responsible for } \\
\text { financial affairs, } 0=\text { else }) \text {. }\end{array}$ & 0.67 & 0.47 & 0 & 1 & 2093 \\
\hline \multicolumn{7}{|l|}{ Benefits (B) } \\
\hline Not much benefit of switching & $\begin{array}{l}\text { Perceived benefit from switching. } \\
\text { Derived from the question: "There can } \\
\text { be different factors that withhold you } \\
\text { from switching. How important are the } \\
\text { factors below? There is not much } \\
\text { benefit from switching." (1 "absolutely } \\
\text { unimportant factor" } 2 \text { "somewhat } \\
\text { important factor" } 3 \text { "not a very }\end{array}$ & 3.55 & 1.05 & 1 & 5 & 2093 \\
\hline
\end{tabular}


Table 7 (continued)

\begin{tabular}{|c|c|c|c|c|c|c|}
\hline Variable & Description & Mean & $\mathrm{Sd}$ & Min & Max & $\mathrm{N}$ \\
\hline & $\begin{array}{l}\text { important factor" } 4 \text { "very improtant } \\
\text { factor" } 5 \text { "extremely important } \\
\text { factor"). }\end{array}$ & & & & & \\
\hline \multicolumn{7}{|l|}{ Switching experience (E) } \\
\hline $\begin{array}{l}\text { Recent switching experience } \\
\text { current account }\end{array}$ & $\begin{array}{l}\text { Binary dummy }(1=\text { switched main } \\
\text { current account less than one year ago, } \\
0=\text { else). }\end{array}$ & 0.02 & 0.15 & 0 & 1 & 2086 \\
\hline $\begin{array}{l}\text { Older switching experience } \\
\text { current account }\end{array}$ & $\begin{array}{l}\text { Binary dummy }(1=\text { switched main } \\
\text { current account at least one year ago, } 0 \\
=\text { else). }\end{array}$ & 0.28 & 0.45 & 0 & 1 & 2086 \\
\hline $\begin{array}{l}\text { Other switching experience } \\
\text { current account }\end{array}$ & $\begin{array}{l}\text { Binary dummy }(1=\text { switching experience } \\
\text { with main savings account, mortgage } \\
\text { loan or revolving credit, } 0=\text { else }) .\end{array}$ & 0.45 & 0.50 & 0 & 1 & 2086 \\
\hline $\begin{array}{l}\text { Recent switching experience } \\
\text { savings account }\end{array}$ & $\begin{array}{l}\text { Binary dummy }(1=\text { switched main } \\
\text { savings account less than one year } \\
\text { ago, } 0=\text { else })\end{array}$ & 0.04 & 0.19 & 0 & 1 & 1889 \\
\hline $\begin{array}{l}\text { Older switching experience } \\
\text { savings account }\end{array}$ & $\begin{array}{l}\text { Binary dummy }(1=\text { switched main } \\
\text { savings account at least one year ago, } \\
0=\text { else }) .\end{array}$ & 0.36 & 0.48 & 0 & 1 & 1889 \\
\hline $\begin{array}{l}\text { Other switching experience } \\
\text { savings account }\end{array}$ & $\begin{array}{l}\text { Binary dummy }(1=\text { switch experience } \\
\text { with main current account, mortgage } \\
\text { loan or revolving credit, } 0=\text { else). }\end{array}$ & 0.41 & 0.49 & 0 & 1 & 1889 \\
\hline $\begin{array}{l}\text { Recent switching experience } \\
\text { mortgage loan }\end{array}$ & $\begin{array}{l}\text { Binary dummy }(1=\text { switched main } \\
\text { mortgage loan less than one year ago, } \\
0=\text { else })\end{array}$ & 0.02 & 0.14 & 0 & 1 & 1087 \\
\hline $\begin{array}{l}\text { Older switching experience } \\
\text { mortgage loan }\end{array}$ & $\begin{array}{l}\text { Binary dummy }(1=\text { switched main } \\
\text { mortgage loan at least one year ago, } 0 \\
=\text { else). }\end{array}$ & 0.42 & 0.49 & 0 & 1 & 1087 \\
\hline $\begin{array}{l}\text { Other switching experience } \\
\text { mortgage loan }\end{array}$ & $\begin{array}{l}\text { Binary dummy }(1=\text { switching experience } \\
\text { with main current account, savings } \\
\text { account or revolving credit, } 0=\text { else }) .\end{array}$ & 0.35 & 0.48 & 0 & 1 & 1087 \\
\hline $\begin{array}{l}\text { Recent switching experience } \\
\text { revolving credit }\end{array}$ & $\begin{array}{l}\text { Binary dummy }(1=\text { switched main } \\
\text { revolving credit less than one year ago, } \\
0=\text { else). }\end{array}$ & 0.03 & 0.16 & 0 & 1 & 181 \\
\hline $\begin{array}{l}\text { Older switching experience } \\
\text { revolving credit }\end{array}$ & $\begin{array}{l}\text { Binary dummy }(1=\text { switched main } \\
\text { revolving credit at least one year ago, } \\
0=\text { else) }\end{array}$ & 0.24 & 0.43 & 0 & 1 & 181 \\
\hline $\begin{array}{l}\text { Other switching experience } \\
\text { revolving credit }\end{array}$ & $\begin{array}{l}\text { Binary dummy }(1=\text { switching experience } \\
\text { with main current account, savings } \\
\text { account or mortgage loan, } 0=\text { else }) .\end{array}$ & 0.49 & 0.50 & 0 & 1 & 181 \\
\hline \multicolumn{7}{|l|}{ Bank-customer relationship (R) } \\
\hline $\begin{array}{l}\text { Customer loyalty current } \\
\text { account }\end{array}$ & $\begin{array}{l}\text { Extent to which one feels a bond with the } \\
\text { bank of one's main current account } \\
\text { ( } 1=\text { no bond at all, } 2=\text { poor bond, } 3= \\
\text { some bond, } 4=\text { strong bond, } 5=\text { very } \\
\text { strong bond). }\end{array}$ & 2.98 & 1.05 & 1 & 5 & 2086 \\
\hline $\begin{array}{l}\text { Customer loyalty savings } \\
\text { account }\end{array}$ & $\begin{array}{l}\text { Extent to which one feels a bond with the } \\
\text { bank of one's main savings account } \\
\text { ( } 1=\text { no bond at all, } 2=\text { poor bond, } 3= \\
\text { some bond, } 4=\text { strong bond, } 5=\text { very } \\
\text { strong bond). }\end{array}$ & 2.94 & 1.05 & 1 & 5 & 1889 \\
\hline $\begin{array}{l}\text { Customer loyalty mortgage } \\
\text { loan }\end{array}$ & $\begin{array}{l}\text { Extent to which one feels a bond with the } \\
\text { bank of one's main mortgage loan }(1= \\
\text { no bond at all, } 2=\text { poor bond, } 3= \\
\text { some bond, } 4=\text { strong bond, } 5=\text { very } \\
\text { strong bond). }\end{array}$ & 2.83 & 1.15 & 1 & 5 & 1087 \\
\hline
\end{tabular}


Table 7 (continued)

\begin{tabular}{|c|c|c|c|c|c|c|}
\hline Variable & Description & Mean & $\mathrm{Sd}$ & Min & Max & $\mathrm{N}$ \\
\hline $\begin{array}{l}\text { Customer loyalty revolving } \\
\text { credit }\end{array}$ & $\begin{array}{l}\text { Extent to which one feels a bond with the } \\
\text { bank of one's main revolving credit } \\
\text { ( } 1=\text { no bond at all, } 2=\text { poor bond, } 3= \\
\text { some bond, } 4=\text { strong bond, } 5=\text { very } \\
\text { strong bond). }\end{array}$ & 2.78 & 1.15 & 1 & 5 & 181 \\
\hline Number of banks & $\begin{array}{l}\text { Number of banks of which one is } \\
\text { customer }(1=1,2=2,3=3,4=4,5 \\
=5 \text { or more). }\end{array}$ & 1.86 & 0.94 & 1 & 5 & 2093 \\
\hline Filed a complaint & $\begin{array}{l}\text { Binary dummy }(1=\text { contacted the bank to } \\
\text { file a complaint during the last three } \\
\text { years, } 0=\text { else })\end{array}$ & 0.08 & 0.28 & 0 & 1 & 2093 \\
\hline \multicolumn{7}{|l|}{ Knowledge (K) } \\
\hline $\begin{array}{l}\text { Knowledge of current } \\
\text { account }\end{array}$ & $\begin{array}{l}\text { Binary dummy }(1=\text { knows the costs of } \\
\text { main current account, } 0=\text { else }) .\end{array}$ & 0.52 & 0.50 & 0 & 1 & 2086 \\
\hline $\begin{array}{l}\text { Knowledge of savings } \\
\text { account }\end{array}$ & $\begin{array}{l}\text { Binary dummy ( } 1=\text { knows the interest } \\
\text { rate on main savings account, } 0= \\
\text { else). }\end{array}$ & 0.65 & 0.48 & 0 & 1 & 1889 \\
\hline Knowledge mortgage loan & $\begin{array}{l}\text { Binary dummy }(1=\text { knows the interest } \\
\text { rate on main mortgage loan, } 0=\text { else }) .\end{array}$ & 0.79 & 0.41 & 0 & 1 & 1087 \\
\hline Knowledge revolving credit & $\begin{array}{l}\text { Binary dummy }(1=\text { knows the interest } \\
\text { rate on main revolving credit, } 0= \\
\text { else). }\end{array}$ & 0.49 & 0.50 & 0 & 1 & 188 \\
\hline \multicolumn{7}{|c|}{ Knowledge of other banking products: } \\
\hline Current account & $\begin{array}{l}\text { Average score on other knowledge } \\
\text { questions than the current account } \\
\text { questions. }\end{array}$ & 0.43 & 0.27 & 0 & 1 & 2086 \\
\hline Savings account & $\begin{array}{l}\text { Average score on other knowledge } \\
\text { questions than the savings account } \\
\text { questions. }\end{array}$ & 0.32 & 0.25 & 0 & 1 & 1889 \\
\hline Mortgage loan & $\begin{array}{l}\text { Average score on other knowledge } \\
\text { questions than the mortgage loan } \\
\text { question. }\end{array}$ & 0.45 & 0.25 & 0 & 1 & 1087 \\
\hline Revolving credit & $\begin{array}{l}\text { Average score on other knowledge } \\
\text { questions than the revolving credit } \\
\text { question. }\end{array}$ & 0.49 & 0.30 & 0 & 1 & 181 \\
\hline $\begin{array}{l}\text { Knowledge of switching } \\
\text { service }\end{array}$ & $\begin{array}{l}\text { Extent to which one is familiar with the } \\
\text { switching service ( } 1=\text { not heard of it, } 2 \\
=\text { heard of it but no knowledge of } \\
\text { content, } 3=\text { heard of it and knowledge } \\
\text { of content). }\end{array}$ & 1.90 & 0.83 & 1 & 3 & 2086 \\
\hline $\begin{array}{l}\text { Knowledge of Deposit } \\
\text { Guarantee Scheme }\end{array}$ & $\begin{array}{l}\text { Binary dummy }(1=\text { knows the DGS, } 0= \\
\text { else). }\end{array}$ & 0.71 & 0.45 & 0 & 1 & 1889 \\
\hline \multicolumn{7}{|l|}{ Socio-psychological factors (S) } \\
\hline $\begin{array}{l}\text { Perceived control over } \\
\text { switching }\end{array}$ & $\begin{array}{l}\text { "If I want, I can switch to another bank" } \\
(1=\text { completely disagree, } 2=\text { disagree, } \\
3=\text { neutral, } 4=\text { agree, } 5=\text { completely } \\
\text { agree). }\end{array}$ & 4.04 & 0.91 & 1 & 5 & 2093 \\
\hline $\begin{array}{l}\text { Degree to which switching is } \\
\text { unpleasant }\end{array}$ & $\begin{array}{l}\text { "Switching to another bank is } \\
\text { unpleasant" ( } 1=\text { completely disagree, } 2 \\
\text { = disagree, } 3=\text { neutral, } 4=\text { agree, } 5= \\
\text { completely agree }) \text {. }\end{array}$ & 3.49 & 0.93 & 1 & 5 & 2093 \\
\hline Injunctive social norms & $\begin{array}{l}\text { "I believe that most people who are } \\
\text { important to me think that I should } \\
\text { switch to another bank" ( } 1=\text { completely } \\
\text { disagree, } 2=\text { disagree, } 3=\text { neutral, } 4= \\
\text { agree, } 5=\text { completely agree }) .\end{array}$ & 1.89 & 0.89 & 1 & 5 & 2093 \\
\hline
\end{tabular}


Table 7 (continued)

\begin{tabular}{|c|c|c|c|c|c|c|}
\hline Variable & Description & Mean & $\mathrm{Sd}$ & Min & Max & $\mathrm{N}$ \\
\hline $\begin{array}{l}\text { Perceived switching } \\
\text { behaviour of others }\end{array}$ & $\begin{array}{l}\text { "People who I would like to resemble } \\
\text { switch banks every now and then" } \\
\text { ( } 1=\text { completely disagree, } 2=\text { disagree, } \\
3=\text { neutral, } 4=\text { agree, } 5=\text { completely } \\
\text { agree). This measures descriptive } \\
\text { social norms. }\end{array}$ & 2.00 & 0.96 & 1 & 5 & 2093 \\
\hline $\begin{array}{l}\text { Jointly owned current } \\
\text { account }\end{array}$ & $\begin{array}{l}\text { Binary dummy }(1=\text { shares current } \\
\text { account, } 0=\text { else }) .\end{array}$ & 0.52 & 0.50 & 0 & 1 & 2086 \\
\hline $\begin{array}{l}\text { Jointly owned savings } \\
\text { account }\end{array}$ & $\begin{array}{l}\text { Binary dummy }(1=\text { shares savings } \\
\text { account, } 0=\text { else })\end{array}$ & 0.56 & 0.50 & 0 & 1 & 1889 \\
\hline Jointly owned mortgage loan & $\begin{array}{l}\text { Binary dummy }(1=\text { shares mortgage } \\
\text { loan, } 0=\text { else }) .\end{array}$ & 0.77 & 0.42 & 0 & 1 & 1087 \\
\hline $\begin{array}{l}\text { Jointly owned revolving } \\
\text { credit }\end{array}$ & $\begin{array}{l}\text { Binary dummy }(1=\text { shares revolving } \\
\text { credit, } 0=\text { else }) .\end{array}$ & 0.58 & 0.49 & 0 & 1 & 181 \\
\hline
\end{tabular}

This table describes the variables used in the regressions reported in Table 1 for the respondents included in these regressions. The mean, standard deviation (sd), minimum ( $\mathrm{min}$ ), maximum ( $\max$ ) and number of observations (N) for DHS variables are based on the data available for the respondents of our additional June 2015 survey 


\section{Appendix 4. The importance of model elements}

Table 8 Propensity to switch main current account

\begin{tabular}{|c|c|c|c|c|c|c|}
\hline & (1) & (2) & (3) & (4) & (5) & (6) \\
\hline Male & $\begin{array}{l}2.45 \\
(2.26)\end{array}$ & & & & & \\
\hline Between 35 and 44 & $\begin{array}{l}1.16 \\
(3.60)\end{array}$ & & & & & \\
\hline Between 45 and 54 & $\begin{array}{l}4.46 \\
(3.59)\end{array}$ & & & & & \\
\hline Between 55 and 64 & $\begin{array}{l}-1.38 \\
(3.58)\end{array}$ & & & & & \\
\hline 65 and over & $\begin{array}{l}-13.63 * * * \\
(3.37)\end{array}$ & & & & & \\
\hline $\begin{array}{l}\text { Education: bachelor degree or } \\
\quad \text { higher }\end{array}$ & $\begin{array}{l}7.58 * * * \\
(2.21)\end{array}$ & & & & & \\
\hline Income category & $\begin{array}{l}0.19 \\
(0.41)\end{array}$ & & & & & \\
\hline Degree of urbanisation & $\begin{array}{l}1.46^{*} \\
(0.78)\end{array}$ & & & & & \\
\hline Responsible for household finances & $\begin{array}{l}1.58 \\
(2.25)\end{array}$ & & & & & \\
\hline Not much benefit of switching & & $\begin{array}{l}-6.19 * * * \\
(1.01)\end{array}$ & & & & \\
\hline $\begin{array}{l}\text { Recent switching experience } \\
\text { current account }\end{array}$ & & & $\begin{array}{l}-1.67 \\
(6.64)\end{array}$ & & & \\
\hline $\begin{array}{l}\text { Older switch experience current } \\
\text { account }\end{array}$ & & & $\begin{array}{l}4.06 \\
(2.59)\end{array}$ & & & \\
\hline $\begin{array}{l}\text { Other switching experience current } \\
\text { account }\end{array}$ & & & $\begin{array}{l}9.09 * * * \\
(2.43)\end{array}$ & & & \\
\hline Customer loyalty current account & & & & $\begin{array}{l}-8.29 * * * \\
(1.02)\end{array}$ & & \\
\hline Number of banks & & & & $\begin{array}{l}3.38 * * * \\
(0.96)\end{array}$ & & \\
\hline Filed a complaint & & & & $\begin{array}{l}17.49 * * * \\
(3.56)\end{array}$ & & \\
\hline Knowledge of current account & & & & & $\begin{array}{l}-2.51 \\
(2.15)\end{array}$ & \\
\hline Knowledge other banking products & & & & & $\begin{array}{l}10.01 * * \\
(4.10)\end{array}$ & \\
\hline Knowledge of switching service & & & & & $\begin{array}{l}1.35 \\
(1.32)\end{array}$ & \\
\hline $\begin{array}{l}\text { Knowledge of switching service * } \\
\text { Recent switching experience } \\
\text { current account }\end{array}$ & & & & & $\begin{array}{l}-1.56 \\
(2.56)\end{array}$ & \\
\hline Perceived control over switching & & & & & & $\begin{array}{l}7.55 * * * \\
(1.26)\end{array}$ \\
\hline $\begin{array}{l}\text { Degree to which switching is } \\
\text { unpleasant }\end{array}$ & & & & & & $\begin{array}{l}-1.35 \\
(1.18)\end{array}$ \\
\hline Injunctive social norms & & & & & & $\begin{array}{l}6.58 * * * \\
(1.47)\end{array}$ \\
\hline $\begin{array}{l}\text { Perceived switching behaviour of } \\
\text { others }\end{array}$ & & & & & & $\begin{array}{l}1.98 \\
(1.29)\end{array}$ \\
\hline Jointly owned current account & & & & & & $\begin{array}{l}0.37 \\
(1.95)\end{array}$ \\
\hline Constant & $\begin{array}{l}-25.48 * * * \\
(4.02)\end{array}$ & $\begin{array}{l}3.55 \\
(3.56)\end{array}$ & $\begin{array}{l}-23.88 * * * \\
(1.85)\end{array}$ & $\begin{array}{l}-1.64 \\
(3.64)\end{array}$ & $\begin{array}{l}-24.19 * * * \\
(3.06)\end{array}$ & $\begin{array}{l}-60.87 * * * \\
(7.89)\end{array}$ \\
\hline Observations & 2086 & 2086 & 2086 & 2086 & 2086 & 2086 \\
\hline Akaike's Information Criterion & 8143.67 & 8159.60 & 8173.49 & 8071.60 & 8199.74 & 8126.41 \\
\hline Ranking & 3 & 4 & 5 & 1 & 6 & 2 \\
\hline
\end{tabular}

Table reports parameter estimates for Tobit regressions. Robust standard errors are in parentheses. The propensity to switch equations of the four different types of banking products are estimated together to allow individual-level errors to be correlated. *** $p<0.01$, ** $p<0.05, * p<0.1$. All models are significant at the $1 \%$ level 
Table 9 Propensity to switch main savings account
(1)
(2)
(3)
(4)
(5)
(6)

\begin{tabular}{ll}
\hline Male & 1.79 \\
& $(2.56)$ \\
Between 35 and 44 & 1.65 \\
& $(4.02)$ \\
Between 45 and 54 & 5.30 \\
& $(4.02)$ \\
Between 55 and 64 & -4.15 \\
& $(4.03)$ \\
65 and over & $-14.71^{* *}$ \\
& $(3.77)$ \\
Education: bachelor degree or higher & $10.24 * * *$ \\
& $(2.49)$ \\
Income category & $0.93 *$ \\
& $(0.47)$ \\
Degree of urbanisation & 1.26 \\
& $(0.86)$ \\
Responsible for household finances & 1.40 \\
& $(2.55)$
\end{tabular}

Not much benefit of switching

Recent switching experience savings account

Older switching experience savings account

Other switching experience savings account

Customer loyalty savings account

Number of banks

$-2.91 * * *$

(1.11)
$39.79 * * *$
(6.10)
$15.76^{* * * *}$
(2.79)
0.03
(2.78)

Filed a complaint

Knowledge of savings account

Perceived control over switching

Degree to which switching is unpleasant

Injunctive social norms

Perceived switching behaviour of

Jointly owned savings account

\section{Constant}

Observations

Akaike's Information Criterion

Ranking

$\begin{array}{ll}-24.18 * * * & -3.99 \\ (4.29) & (4.14) \\ 1889 & 1889 \\ 8456.67 & 8525.68 \\ 3 & 6\end{array}$
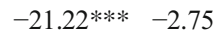

$-25.18 * * *-53.94 * * *$

(2.73) (8.48)

$1889 \quad 1889$

$8511.46 \quad 8492.53$

54

Table reports parameter estimates for Tobit regressions. Robust standard errors are in parentheses. The propensity to switch equations of the four different types of banking products are estimated together to allow individual-level errors to be correlated. $* * * p<0.01, * * p<0.05, * p<0.1$. All models are significant at the $1 \%$ level 
Table 10 Propensity to switch main mortgage loan

\begin{tabular}{l}
\hline Male \\
Between 35 and 44 \\
Between 45 and 54 \\
Between 55 and 64 \\
65 and over \\
Education: bachelor degree \\
or higher \\
Income category \\
Degree of urbanisation \\
Responsible for household finances \\
Not much benefit of switching \\
Recent switching experience \\
mortgage loan \\
Older switching experience \\
mortgage loan \\
Other switching experience \\
mortgage loan \\
Customer loyalty bank mortgage \\
loan \\
Number of banks
\end{tabular}

Filed a complaint

Knowledge of mortgage loan

Knowledge of other banking products

Perceived control over switching

Degree to which switching

$$
\text { is unpleasant }
$$

Injunctive social norms

Perceived switching behaviour

$$
\text { of others }
$$

Jointly owned mortgage loan

\section{Constant}

Observations

Akaike's Information Criterion

Ranking

\section{(1)}

0.74

(4.19)

$-5.32$

(6.58)

$-1.89$

(6.89)

$-18.55 * * *$

(6.88)

$-22.10^{* * * *}$

(6.93)

$-4.77$

(3.86)

$2.51 * * *$

$(0.81)$

1.57

(1.39)

$-2.24$

(3.98)

(2) (3)

(4)

(5)

(6)

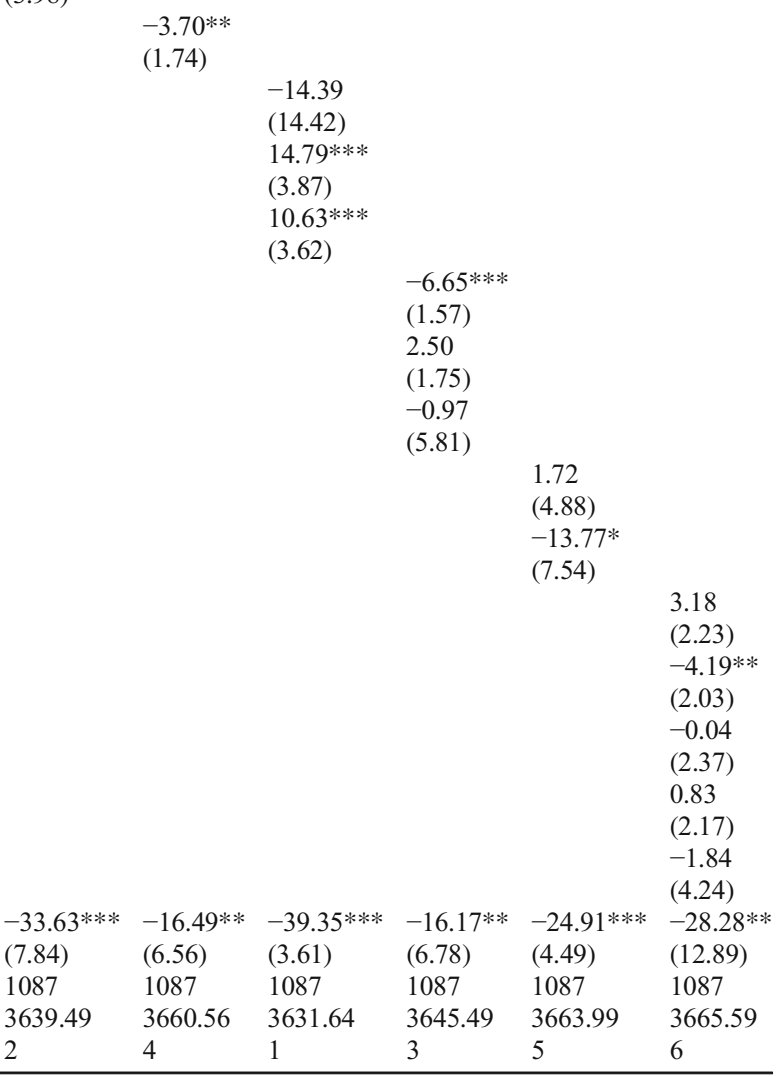

Table reports parameter estimates for Tobit regressions. Robust standard errors are in parentheses. The propensity to switch equations of the four different types of banking products are estimated together to allow individual-level errors to be correlated. $* * * p<0.01, * * p<0.05, * p<0.1$. The last two specifications are not statistically significant. The other specifications are significant 
Open Access This article is distributed under the terms of the Creative Commons Attribution 4.0 International License (http://creativecommons.org/licenses/by/4.0/), which permits unrestricted use, distribution, and reproduction in any medium, provided you give appropriate credit to the original author(s) and the source, provide a link to the Creative Commons license, and indicate if changes were made.

\section{References}

Accenture (2016) Banking on value: rewards, robo-advice and relevance Retrieved from https:/www.accenture. com/us-en/insight-consumer-digital-banking-survey-2016

ACM (2014) Barriers to entry into the Dutch retail banking sector Retrieved from https://www.acm. nl/en/publications/publication/13257/Barriers-to-entry-into-the-Dutch-retail-banking-sector/

Akaike H (1974) A new look at the statistical model identification. IEEE Trans Autom Control 19(6):716-723

Amel DF, Kennickell AB, Moore KB (2008) Banking market definition: evidence from the survey of consumer finances. Finance and Economics discussion series 2008-35. Retrieved from https://www.federalreserve. gov/pubs/feds/2008/200835/200835pap.pdf

Antón C, Camarero C, \& Carrero, M (2007) Analysing firms' failures as determinants of consumer switching intentions. Eur J Mark, 41(1/2):135-158

Australian Government (2015) Improving Australia's financial system: government response to the financial system inquiry Retrieved from http://treasury.gov.au/ /media/Treasury/Publications $\% 20$ and $\% 20$ Media/Publications/2015/Government\%20response $\% 20$ to $\% 20$ the $\% 20$ Financial $\% 20$ System $\% 20$ Inquiry/Downloads/PDF/Government_response_to_FSI_2015.ashx

Beck T, De Jonghe O, Schepens G (2013) Bank competition and stability: cross-country heterogeneity. J Financ Intermed 22(2):218-244

Boot AWA, Thakor AV (1994) Moral hazard and secured lending in an infinitely repeated credit market game. Int Econ Rev 35(4):899-920

Brown M, Guin B, Morkoetter S (2016) Deposit withdrawals from distressed commercial banks: the importance of switching costs. University of St. Gallen, School of Finance Research Paper no. 2013-19. Retrieved from https://papers.ssrn.com/sol3/Papers.cfm?abstract_id=2354197

Brunetti M, Ciciretti R, Djordjevic L (2016) The determinants of household's bank switching. J Financ Stab 26:175-189

CBS (2017) Consumptief krediet 1998-2013. Retrieved from http://statline.cbs.nl/Statweb/publication/?DM= SLNL\&PA=70699ned \&D1=0-15\&D2=0\&D3=168-192\&HDR=T\&STB=G1,G2\&VW=T

CEG (2014) Overdrafts on personal current accounts: a study into market power Retrieved from https://www. acm.nl/en/publications/publication/13045/Study-CEG-Overdrafts-on-personal-current-accounts/

Chakravarty S, Feinberg R, Rhee EY (2004) Relationships and individuals bank switching behavior. J Econ Pyschol 25:507-527

Competition \& Markets Authority (2015a) Retail banking market investigation: updates issues statement Retrieved from https://www.gov.uk/government/uploads/system/uploads/attachment_data/file/428973 /Updated_Issues_Statement_2015.pdf

Competition \& Markets Authority (2015b) Retail banking market investigation: Dutch retail banking market case study Retrieved from https://assets.publishing.service.gov.uk/media/55bb4207ed915d1568000003/Dutch retail_banking_market_case_study.pdf

Consumentenbond (2016) Betaalrekeningen vergelijken Retrieved from https://www.consumentenbond. $\mathrm{nl} /$ betaalrekening/vergelijker?sortDirection=asc \&productGroup=BETAALR\&sortCriterion $=$ prijsVanaf\&pageSize $=18 \&$ page $=1 \&$ prijs Vanaf $=0 \&$ prijsTot $=180$

De Nederlandsche Bank (2015a) Annu Rep 2014. Retrieved from http:/www.dnb.nl/en/binaries/jv2014\%20uk tcm47-319635.pdf

De Nederlandsche Bank (2015b) Perspective on the structure of the Dutch banking sector Retrieved from http://www.dnb.nl/en/binaries/DNB-study\%20Perspective\%20on\%20the\%20structure\%20of\%20the \%20 Dutch\%20banking\%20sector_tcm47-323322.pdf

De Nederlandsche Bank (2016) Langere rentevaste periode bij nieuwe woninghypotheek populairder Retrieved from https://www.dnb.nl/nieuws/nieuwsoverzicht-en-archief/statistisch-nieuws-2016/dnb341004.jsp

Ek K, Söderholm P (2008) Households switching behavior between electricity suppliers in Sweden. Util Policy 16:254-261

European Commission (2006) Interim report II: Current accounts and related services Retrieved from http://ec. europa.eu/competition/sectors/financial_services/inquiries/interim_report_2.pdf 
European Commission (2012) Retail financial services report (Eurobarometer 373) Retrieved from https://data. europa.eu/euodp/en/data/dataset/S990_76_1_EBS373

European Commission (2013) Switching payment accounts. Directive on payment accounts - Factsheet 2. Retrieved from http://ec.europa.eu/finance/finservices-retail/docs/inclusion/20130506-factsheet-2_en.pdf

EY (2013) Protecting the future: Canadian Retail Banking Survey 2013. Retrieved from http:/www.ey. com/Publication/vwLUAssets/Canadian-Retail-Banking-Survey-2013/\$FILE/Canadian-Retail-BankingSurvey-2013.pdf

Farrell J, Klemperer P (2007) Chapter 31 coordination and lock-in: competition with switching costs and network effects. Handb Ind Organ 3:1967-2072

Federal Reserve (2014) 9. What product markets does the Federal Reserve typically consider for bank merger applications? Retrieved from https:/www.federalreserve.gov/bankinforeg/competitive-effects-mergersacquisitions-faqs.htm\#fn2

Fischhoff B, Bruine de Bruin W (1999) Fifty-fifty = 50\%? J Behav Decis Mak 12:149-163

Frank RG, Lamiraud K (2009) Choice, price competition and complexity in markets for health insurance. J Econ Behav Organ 71:550-562

Gamble A, Juliusson EA, Gärling T (2009) Consumer attitudes towards switching supplier in three deregulated markets. J Socio-Econ 38(5):814-819

Georgarakos D, Haliassos M, Pasini G (2014) Household debt and social interactions. Rev Financ Stud 27(5): 1404-1433

Gfk (2014) Consumer survey on personal accounts Retrieved from https://www.acm. $\mathrm{nl} / \mathrm{nl} /$ publicaties/publicatie/13039/GfK-enquete-onder-consumenten-met-een-betaalrekening/

Giulietti M, Waddams Price CW, Waterson M (2005) Consumer choice and competition policy: a study of UK energy markets. Econ J 115:949-968

Hurd M, Van Rooij M, Winter J (2011) Stock market expectations of Dutch households. J Appl Econ 26(3):416-436

Inakura N, Shimizutani S (2010) Deposit insurance and depositor discipline: direct evidence on bank switching behaviour in Japan. Appl Econ 42(26):3401-3415

Ioannidou V, Ongena S (2010) "Time for a Change". Loan conditions and Bank behavior when firms switch banks. J Financ 65(5):1847-1877

Juster FT (1966) Consumer buying intentions and purchase probability: an experiment in survey design. J Am Stat Assoc 61(315):658-696

Kiser EK (2002) Predicting household switching behavior and switching cost at depository institutions. Rev Ind Organ 20:349-365

Manski CF (2004) Measuring expectations. Econometrica 72(5):1329-1376

Murray D, Davis K, Dunn C, Hewson C, McNamee B (2014) Financial system inquiry final report Retrieved from http://fsi.gov.au/files/2014/12/FSI_Final_Report_Consolidated20141210.pdf

National Forum on the Payment System (2016a) Accessibility monitor 2016. Accessibility monitor 2016. Written by the working group on availability and accessibility. Retrieved from http://www.dnb. nl/binaries/Accessibility\%20Monitor\%202016 tcm46-349693.pdf?2016120111

National Forum on the Payment System (2016b) The NFPS's vision on improving customer mobility in the retail payments market Retrieved from: https://www.dnb.nl/en/binaries/NFPS\%20vision\%20on\%20mobility\%20 in\%20the\%20retail\%20payments\%20market\%205\%20July\%202016_tcm47-343528.pdf?2017011910

Ongena S, Smith DC (2001) The duration of bank relationships. J Financ Econ 61(3):449-475

Papalia RB, Di Iorio F (2001) Alternative error term specification in the log-Tobit model. In: Borra S, Rocci R, Schader M, Vichi M (eds) Advances in classification and data analysis. Springer, Eidelberg, pp 185-192

Siamagka NT, Balabanis G (2015) Revisiting consumer ethnocentrism: review, reconceptualization, and empirical testing. J Int Mark 23(3):66-86

Teppa F, Vis C (2012) The CentERpanel and the DNB household survey: methodological aspects. DNB Occasional Study 10(4). Retrieved from http://www.dnb.nl/binaries/DNB_OS_1004_BIN_WEB_tcm46-277691.pdf

Van der Cruijsen CAB, De Haan J, Jansen D, Mosch RHJ (2011) Household savings behavior in crises times. DNB working paper no. 315. Retrieved from http://www.dnb.nl/binaries/wp315_tcm46-257193.pdf

Van der Cruijsen CAB, De Haan J, Jansen D, Mosch RHJ (2012) Households decisions on savings accounts after negative experiences with banks during the financial crisis. J Consum Aff 46(3):436-456

Von Gaudecker H-M (2015) How does household portfolio diversification vary with financial literacy and financial advice? J Financ 70(2):489-507

Von Thadden E-L (1995) Long-term contracts, short-term investment and monitoring. Rev Econ Stud 62(4):557-575

Webb TL, Sheeran P (2006) Does changing behavioral intentions engender behavior change? A meta-analysis of the experimental evidence. Psychological Bulletin 132 (2):249-268

Wooldridge JM (2002) Econometric analysis of cross section and panel data. MIT Press, Cambridge 
Worldbank (2013) Rethinking the role of the state in finance. Global financial development report. Retrieved from https://openknowledge.worldbank.org/bitstream/handle/10986/11848/Global\%20Financial\%20 Development\%20Report\%202013.pdf?sequence=1

Yang Y (2014) Understanding household switching behaviour in the retail electricity market. Energ Policy 69: 406-414 